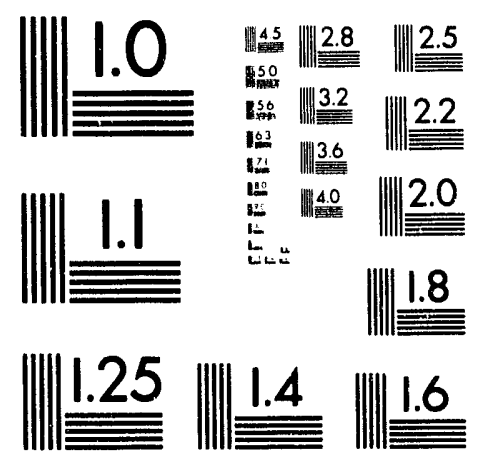



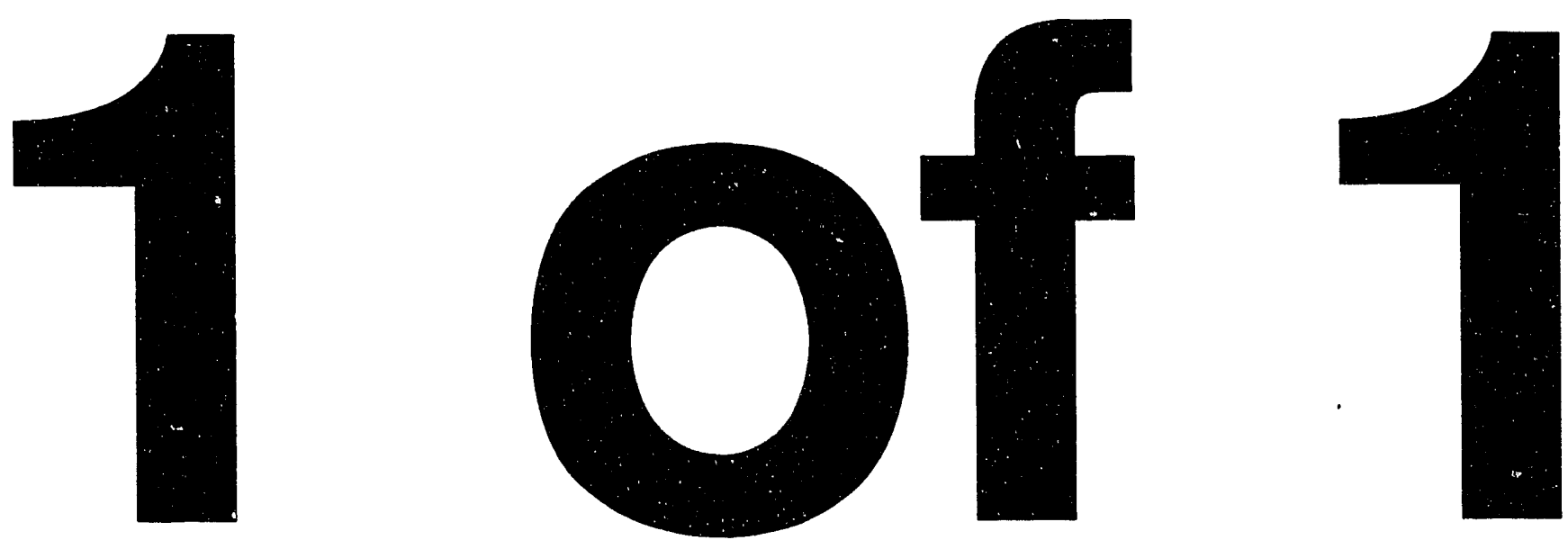
ORNL/GWPO-003

Environmental Sciences Division

\title{
The Deep Hydrogeologic Flow System Underlying the Oak Ridge Reservation
}

\author{
R. Nativ \\ A. E. Hunley
}

Date Issued_July 1993

Prepared by

Environmental Sciences Division

Oak Ridge National Laboratory

ESD Publication 4097

OAK RIDGE NATIONAL LABORATORY

Oak Ridge, Tennessee 37831-6285 managed by

MARTIN MARIETTA ENERGY SYSTEMS, INC.

for the

U.S. DEPARTMENT OF ENERGY under contract DE-AC05-84OR21400 


\section{Author Affiliations}

R. Nativ is employed by the Hebrew University of Jerusalem, Israel. A. E. Hunley is a member of the Environmental Sciences Division of Oak Ridge National Laboratory. 


\section{CONTENTS}

FIGURES $\ldots \ldots \ldots \ldots \ldots \ldots \ldots \ldots \ldots \ldots \ldots \ldots \ldots \ldots \ldots \ldots$

ACKNOWLDGEMENTS $\ldots \ldots \ldots \ldots \ldots \ldots \ldots \ldots \ldots \ldots \ldots \ldots$ vii

ABSTRACT $\ldots \ldots \ldots \ldots \ldots \ldots \ldots \ldots \ldots \ldots \ldots \ldots \ldots \ldots \ldots \ldots \ldots \ldots \ldots$

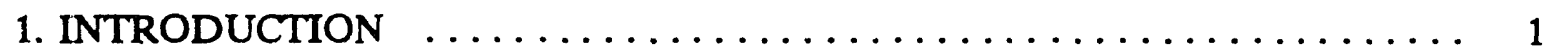

2. STATEMENT OF THE PROBLEM $\ldots \ldots \ldots \ldots \ldots \ldots \ldots \ldots \ldots$

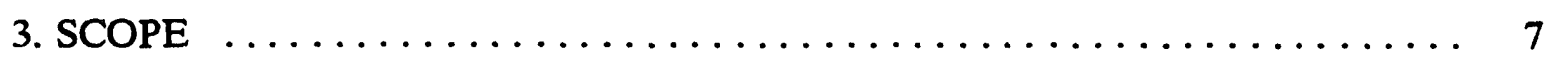

4. RESEARCH METHODS $\ldots \ldots \ldots \ldots \ldots \ldots \ldots \ldots \ldots \ldots \ldots$

5. RESULTS AND DISCUSSION $\ldots \ldots \ldots \ldots \ldots \ldots \ldots \ldots \ldots \ldots \ldots$

5.1 HYDRAULIC HEAD AND PRESSURE $\ldots \ldots \ldots \ldots \ldots \ldots \ldots \ldots \ldots$

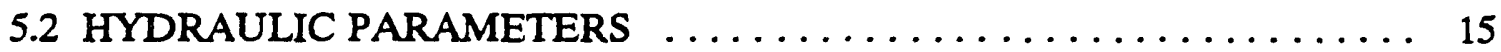

5.3 TEMPERATURE VARIATIONS $\ldots \ldots \ldots \ldots \ldots \ldots \ldots \ldots \ldots \ldots \ldots$

5.4 CHEMICAL AND ISOTOPIC COMPOSITION $\ldots \ldots \ldots \ldots \ldots \ldots \ldots \ldots . \ldots \ldots$

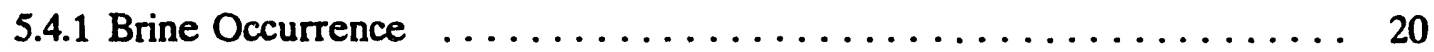

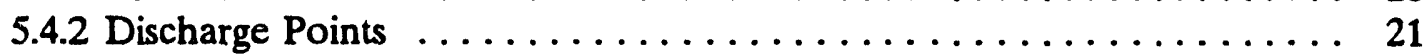

5.4.3 Spatial Variations of Brine Concentrations .............. 21

5.4.4 Temporal Variation of Brine Concentrations ............. 22

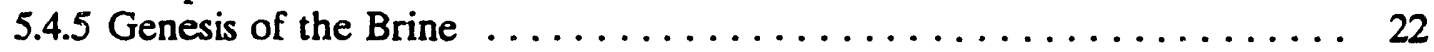

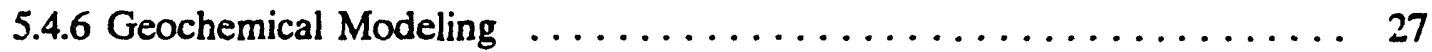

6. CONCLUSIONS $\ldots \ldots \ldots \ldots \ldots \ldots \ldots \ldots \ldots \ldots \ldots \ldots \ldots \ldots$

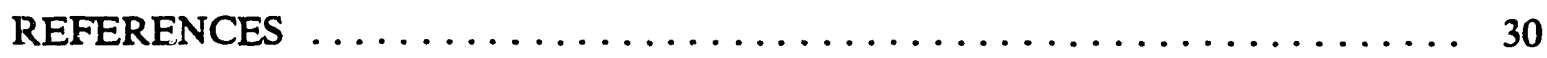

Appendix A: INFORMATION ABOUT THE PACKED BOREHOLES $\ldots \ldots \ldots 35$

Appendix B: INFORMATION ABOUT THE OIL AND GAS WELLS SAMPLED FOR THIS STUDY $\ldots \ldots \ldots \ldots \ldots \ldots \ldots \ldots \ldots \ldots \ldots \ldots \ldots \ldots \ldots \ldots \ldots \ldots \ldots$

Appendix C: ION RATIOS IN BRINES, THE APPALACHIAN REGION $\ldots \ldots \quad 39$ 


\section{FIGURES}

$1 \quad$ Location map (after Geraghty \& Miller 1987b) $\ldots \ldots \ldots \ldots \ldots$

2 Geohydrologic map (from Solomon et al. 1992) for the

Oak Ridge Reservation $\ldots \ldots \ldots \ldots \ldots \ldots \ldots \ldots \ldots \ldots \ldots$

3 Location map for the deep wells in the area $\ldots \ldots \ldots \ldots \ldots \ldots$

4 Stratigraphic column for the Oak Ridge Reservation $\ldots \ldots \ldots \ldots \ldots \ldots$

$5 \quad$ Water levels for the HHMS wells (June 25,1992$) \ldots \ldots \ldots \ldots \ldots$

$6 \quad$ Water level in HHMS clusters 7 and 3 during $1991 \ldots \ldots \ldots \ldots \ldots$

$7 \quad$ General description of core from the Joy-1 well and water level

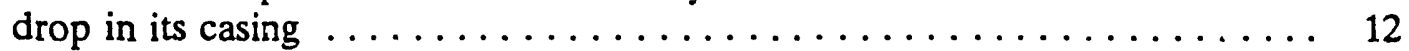

8 Water level variations in the packed intervals of five deep wells $\ldots \ldots \ldots 14$

9 Resistivity logs from WCR-2 and from $\mathrm{CH}-5$ wells $\ldots \ldots \ldots \ldots \ldots$

$10 \quad$ Groundwater flux through fractures in $\mathrm{CH}-9$ corehole $\ldots \ldots \ldots \ldots \ldots$

11 Temperature logs from $\mathrm{CH}-6$ and $\mathrm{CH}-9$ wells $\ldots \ldots \ldots \ldots \ldots \ldots$

12 Oxygen-18 and deuterium data from HHMS $2 \mathrm{a}, 5 \mathrm{a}$, and $6 \mathrm{a}$, where saline water was found and from oil and gas wells

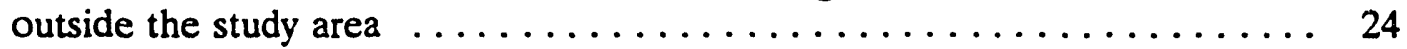

$13 \quad \mathrm{Na}: \mathrm{Cl}$ and $\mathrm{Ca}: \mathrm{Cl}$ ratios for deep brine $\ldots \ldots \ldots \ldots \ldots \ldots \ldots \ldots \ldots$

$14 \quad \mathrm{Br}: \mathrm{Cl}$ ratio for the deep brine $\ldots \ldots \ldots \ldots \ldots \ldots \ldots \ldots \ldots \ldots \ldots$ 


\section{ACKNOWLEDGMENTS}

The authors are very grateful to the many people who made this work possible. The many efforts of Kip Solomon and RaNaye Dreier facilitated the work of this project. Kip Solomon and Norman Farrow designed the packer/pressure transducer assembly that allowed us to monitor pressure variations in the deep wells with high resolution. Scott Gregory assisted with setting the pressure transducers and with data logging and do'rnloading. Bob Kennard and Kim Davis helped in the logging of the deep wells. Andy Hunt assisted with setting the packers. Kip Solomon and Andy Hunt designed the purging system of the deep wells. Tom Zondlo and Scott Gregory prepared Figs. 1 and 7, respectively. RaNaye Dreier, Steve Haase, Peter Lemiszki, Bill McMaster, Gerry Moore, Craig Rightmire, Paul Rubin, Lisa Shevenell, Kip Solomon, Laura Toran, and Tom Zondlo were inspiring partners during the design of this project and the interpretation of the results. Lisa Shevenell reviewed the manuscript and improved it significantly. 


\begin{abstract}
The deep hydrogeologic system underlying the Oak Ridge Reservation contains some areas contaminated with radionuclides, heavy metals, nitrates, and organic compounds. The groundwater at that depth is saline and has previously been considered stagnant. On the basis of existing and newly collected data, the nature of flow of the saline groundwater and its potential discharge into shallow, freshwater systems was assessed. Data used for this purpose included (1) spatial and temporal pressures and hydraulic heads measured in the deep system, (2) hydraulic parameters of the formations in question, (3) spatial temperature variations, and (4) spatial and temporal chemical and isotopic composition of the saline groundwater. In addition, chemical analyses of brine in adjacent areas in Tennessee, Kentucky, Ohio, Pennsylvania, and West Virginia were compared with the deep water underlying the reservation to help assess the origin of the brine. Preliminary conclusions suggest that the saline water contained at depth is old but not isolated (in terms of recharge and discharge) from the overlying active and freshwater-bearing units. The confined water (along with dissolved solutes) moves along ope il fractures (or man-made shortcuts) at reiatively high velocity into adjacent, more permeable units. Groundwater volumes involved in this flow probably are small.
\end{abstract}




\section{INTRODUCTION}

The Oak Ridge Reservation (ORR) is located in eastern Tennessee at the northwestern edge of the Valley and Ridge prnvince and east of the Appalachian Mountain belt (Figs. 1-3). The climate is temperate, and annual precipitation is $\sim 1370 \mathrm{~mm}$ (54 in.) (National Oceanic and Atmospheric Administration 1984). The ORR was founded as part of the Manhattan Project in the early 1940 s and belongs to the U.S. Department of Energy. The reservation hosts several production, research and development, and nuclear facilities as well as numerous hazardous waste disposal and storage sites.

The ORR is underlain by a suite of aquitards formed in shales, limestone, and dolomite of the Conasauga (middle Cambrian) and the Chickamauga (middle Ordovician) groups. The Knox Group (upper Cambrian and lower Ordovician) (Fig. 4) contains the only aquifer in the area. Groundwater is fresh [ $<500 \mathrm{mg} / \mathrm{L}$ of total dissolved solids (TDS)], and its flow is controlled by the density of fractures in the aquitards and dissolution channels in the carbonate aquifer (Solomon et al. 1992). Consequently, $\sim 90 \%$ of the subsurface flow is believed to be in the 1- to 2-m-deep stormflow zone (Moore 1988), and almost all (98\%) subsurface flow in areas underlain by aquitards is believed to be at depths $<30 \mathrm{~m}(-90 \mathrm{ft})$, where fractures and dissolution channels are closely spaced (Solomon et al. 1992). Subsurface flow paths from recharge to discharge zones are presumably short, generally $<1.6 \mathrm{~km}$ ( $<1$ mile), and do not exceed a few miles (Solomon et al. 1992). Consequently, the Clinch River surrounding the ORR on three sides is the main discharge point and is generally considered a hydrologic boundary for the reservation.

The active, shallow groundwater is underlain by a deeper system, referred to as an aquiclude (Solomon et al. 1992), that contains brine ( $\sim 200,000 \mathrm{mg} / \mathrm{L}$ TDS). It is assumed that groundwater in this system is nearly stagnant and not included in the active subsurface circulation (Chapman-Bailey and Lee 1991; Solomon et al. 1992). The stagnancy of the deep groundwater was inferred from its very high salinity. The assumption is that if active groundwater circulation could take place in this zone, the brine should have been flushed away long ago. A transition zone separates the actively flowing shallow groundwater system from the underlying aquiclude. Groundwater salinity in the transition zone ranges from 500 to tens of thousands milligrams per liter of TDS. 


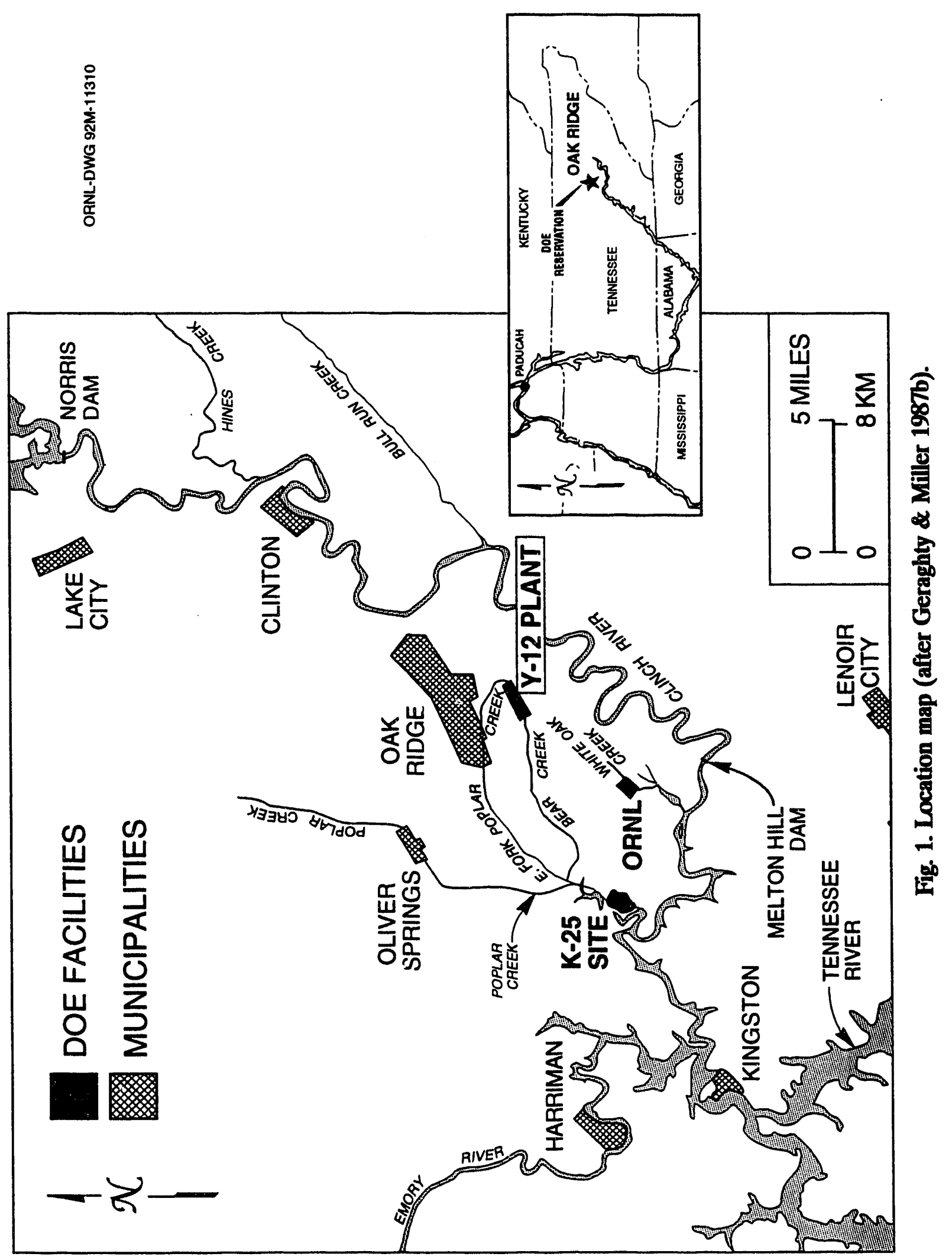




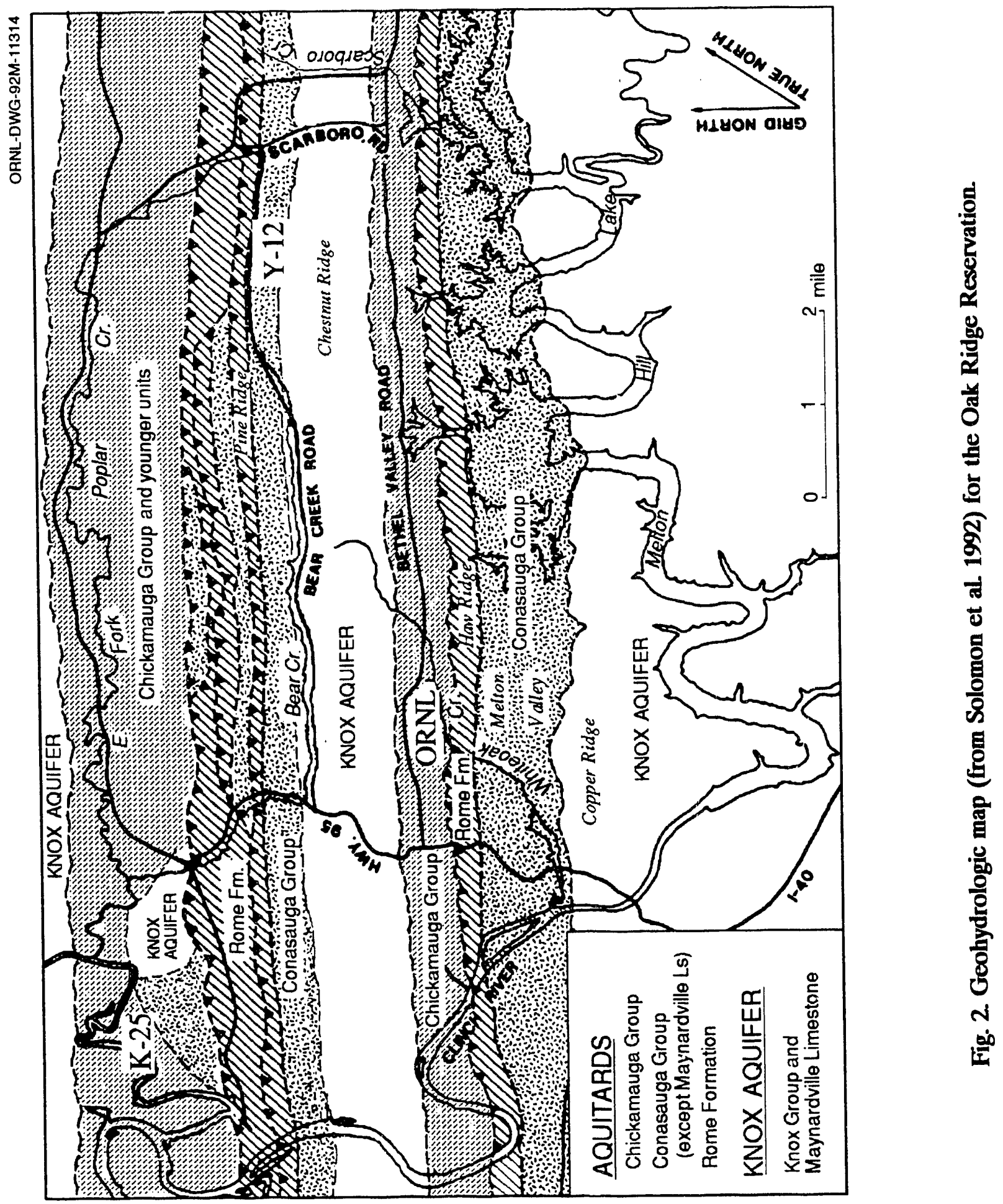




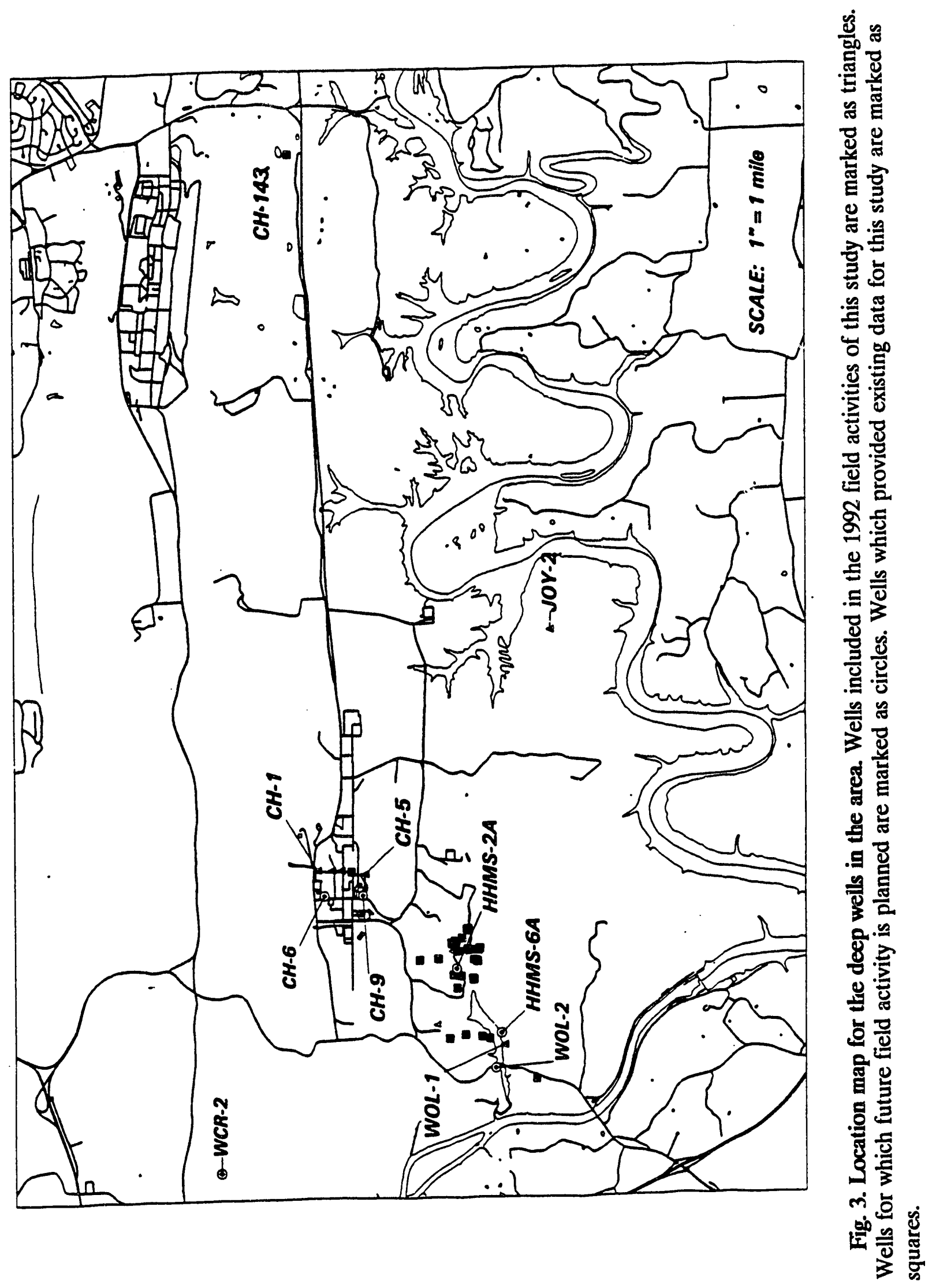



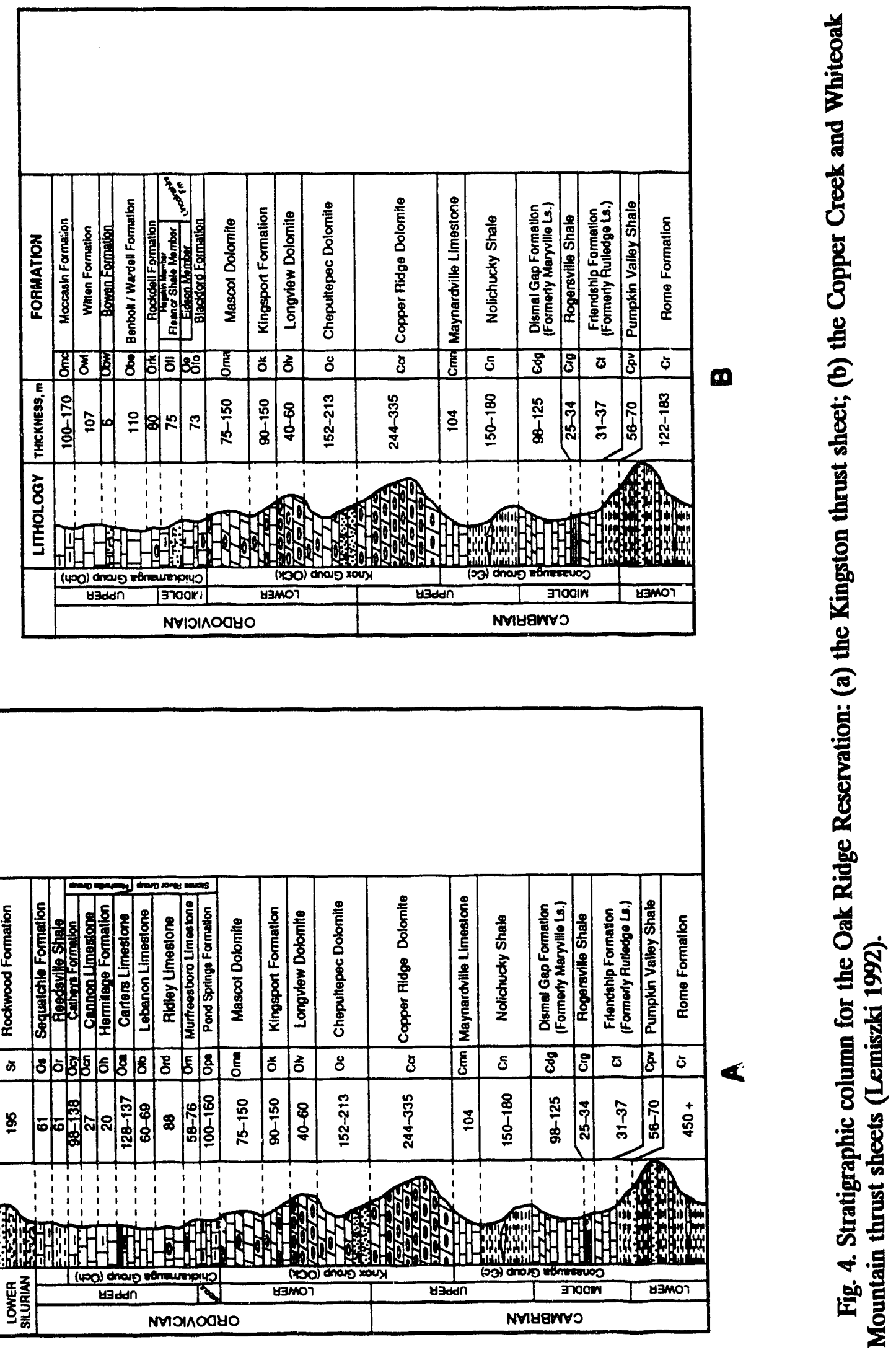


\section{STATEMENT OF THE PROBLEM}

Groundwater contamination has been observed in several locations within the ORR, and various methods of remediation are currently being tested or evaluated. There is evidence that contaminants such as radionuclides, nitrates, tritium, heavy metals, dense nonaqueous phase liquids (DNAPLs), and volatile organic compounds (VOCs) have also reached the deep "inactive" groundwater system or the overlying transition zone in several locations (Dreier et al. 1991; Dreier and Toran 1989; Geraghty and Miller, Inc. 1987a; Haase and King 1990). The presence of contaminants in deep locations other than the points of deep-well injection of waste (Stow and Haase 1986) has been interpreted as density-driven flow, rather than active circulation through the trarisition zone or the deep system (e.g., Dreier et al. 1991). If the deep system is nearly stagnant, subsurface movement of contaminants on a regional scale is unlikely. Consequently, remediation efforts of known deep-seated contaminants would be of low priority because their migration is likely to be retarded significantly. If, however, groundwater circulation within the deep system is active and flows to the shallow, freshwater system o: to surface streams, then cleanup or control of the deep-seated contaminants should be considered a high priority, particularly because deeper systems are likely to develop longer flow paths to natural outlets (Toth 1963). Discharge points for the deep system, therefore, may exist beyond the Clinch River and the ORR boundaries, which is clearly an undesirable prospect and one that merits examination. 


\section{SCOPE}

Although several previous studies have examined the deep groundwater system at specific locations (e.g., Dreier and Toran 1989; Stow and Haase 1986; Dreier et al. 1991), this study is the first attempt to directly monitor and evaluate groundwater flow and solute migration in the deep hydrogeologic system underlying the entire ORR. The study was designed to address the following questions: Is groundwater in the deep system stagnant? If it is flowing, at what rate? Is contaminant migration a itrolled by diffusion only, or is advection a viable mechanism? Where are the potential outlet points?

These are intriguing questions in a sense far broader than the immediate remediation needs of the ORR. Saline groundwater can be found at depth anywhere within the eastern and central United States (Brown et al. 1979; Clifford 1973; Garven and Sverjensky 1989; Goodman 1990; Heck et al. 1964; Kreiger et al. 1957; Lamborn 1952; Milhouse 1959; Poth 1962; Price et al. 1937; Rose and Dresel 1990; Startler el al. 1975; Stout et al. 1932). The controlling mechanisms accountable for the formation and the preservation of brine at depths of $200 \mathrm{~m}(650 \mathrm{ft})$ or less in these humid regions are not always clear. The use of subsurface low-permeability, brine-containing environments for hazardous and nuclear waste isolation has been proposed and explored at several locations across the United States (Brown et al. 1979). The generic questions listed in the preceding paragraph should be addressed whenever subsurface isolation of hazardous waste is being considered under similar conditions. 


\section{RESEARCH METHODS}

The geologic heterogeneity, the small geographical area, and the small number of deep wells account for some of the difficulties encountered during the study of the deep hydregeological system of the ORR. These are typical problems for almost any study of deep hydrologic systems. To partially overcome these problems, data were collected from (1) all possible stratigraphic and lithologic settings (limestone, dolomite, and shale) and from all geologic groups (saline water was encountered in all rocks and rock units) and (2) observation points that covered as much area as possible within the ORR. To aid in conceptualization, these observations were supplemented by data from a few deep wells outside the ORR.

Groundwater features indicative of active circulation in the deep system and of potential hydraulic connection with the shallow hydraulic system include (1) hydraulic head/pressure distribution and variations, (2) evidence of high permeability, (3) temperature variations, (4) chemical and stable isotope composition, and (5) groundwater age indicators. Because the deep system is complex and because data and observation points are sparse, attempts were made to assess its activity by using all of these features. This approach provides independent evidence from various aspects. 


\section{RESULTS AND DISCUSSION}

\subsection{HYDRAULIC HEAD AND PRESSURE}

When data from well clusters are being used, the comparison of water levels in cased boreholes or piezometers is useful for the assessment of (1) the lateral hydraulic connection and (2) the direction of potential vertical flow. The monitoring of temporal water level variations may help in evaluating (1) the degree of confinement of the deep system (by assessing pressure response to earth tide and barometric pressure) and (2) the current recharge of its groundwater.

Only two sets of wells could be used to assess hydraulic connectivity across the deep system and the potential of lateral groundwater flow. To be suitable, the wells had to (1) penetrate the same geologic group, (2) have small open intervals, and (3) be relatively close to each other. These well sets include the Hydraulic Head Measuring Stations (HHMS) wells and the Rock Cover wells, both penetrating the shale and limestone of the Conasauga Group in Melton Valley. Whereas the uncased intervals of the HHMS wells are open to the Pumpkin Valley Shale, Rogersville Shale, Maryville Limestone, and Nolichucky Shale formations, the Rock Cover wells tap only the Rogersville Shale and the Rutledge Limestone. To date, the Rock Cover wells cannot be accessed, but water level measurements taken at the HHMS wells suggest hydraulic continuity between the wells (Fig. 5).

Comparison of water levels in the deep and shallow systems in well clusters such as the HHMS wells allows definition of potential vertical flow. Hydraulic heads in the deep system are lower than those in the shallow system in HHMS 1, 6, 7, 9, and 11 , suggesting the potential for recharge from above (well 7, Fig. 6); however, wells 6, 9, and 11 may not be fully recovered. In other HHMS wells $(2,3,10$, and 13$)$ water levels in the deep system are higher, suggesting the potential for upward leakage from below (well 3, Fig. 6). Similar observations were documented in a deeper well (WOL-2, Fig. 3) in the Conasauga Group, where water level measured in a packed interval ranging from 268 to $276 \mathrm{~m}(880$ to $907 \mathrm{ft})$ below land surface was $0.4 \mathrm{~m}(1.2 \mathrm{ft})$ higher than water levels measured above it. Packed intervals in the bottom of coreholes in the Chickamauga Group ( $\mathrm{CH}-1,7$, and 9, X-10 area) also displayed higher water levels than those measured above them (Environmental Restoration Program 1992). The documented higher hydraulic heads in some of the deep wells suggest that, at least in these areas, recharge into the deep system cannot come directly from above but may reach this zone from more remote, higher elevation areas.

Unusually low pressures were observed at the bottom of several deep wells, such as Joy-1, HHMS13, and GW-134 (Bear Creek Valley). The high hydraulic head at depth and the subsequent head drop below it at the bottom of GW-134 were thought to result from density-driven flow in response to a nearby source of acidic, dense, $\mathrm{NO}_{3}$-contaminated water (Dreier et al. 1991). There is no obvious explanation for the increase of hydraulic head in the HHMS13 well to $268 \mathrm{~m}$ ( $880 \mathrm{ft}$ ) at a depth of 99 to $125 \mathrm{~m} \mathrm{(325} \mathrm{to} 409 \mathrm{ft})$, followed by a head drop to $240 \mathrm{~m}$ (790 ft) below (R. Dreier, Oak Ridge National Laboratory, personal

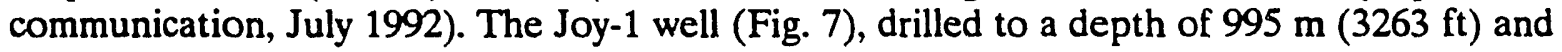
cased to $884 \mathrm{~m}(2900 \mathrm{ft}$ ), was filled with water to the surface on October 16, 1962. Soon, this water level was below that of the Watts Bar Dam (or the predamming stage of the Clinch River), which determined the lowest possible level of the water table for a wide surrounding 


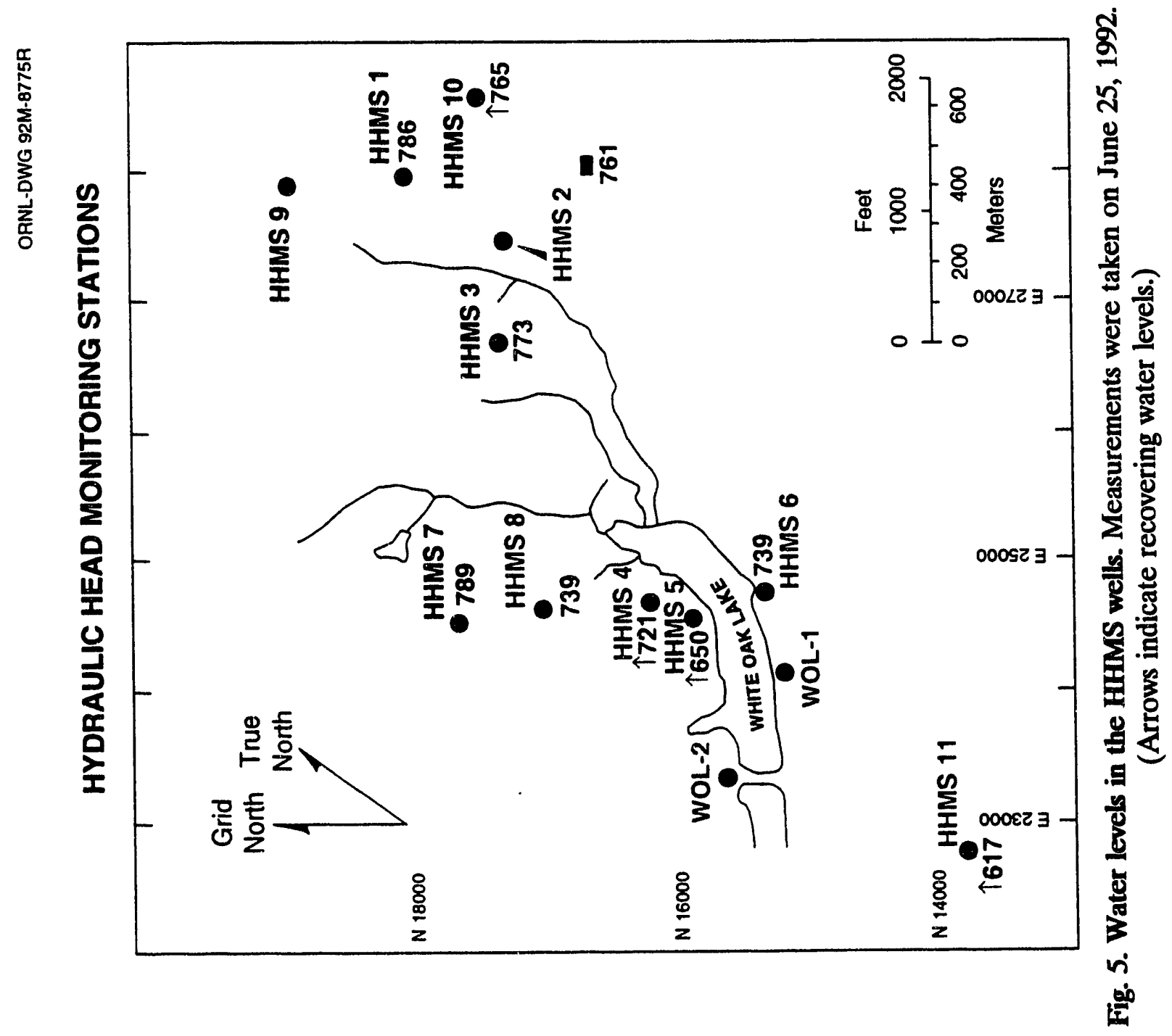


ORNL-DWG 92M-12145
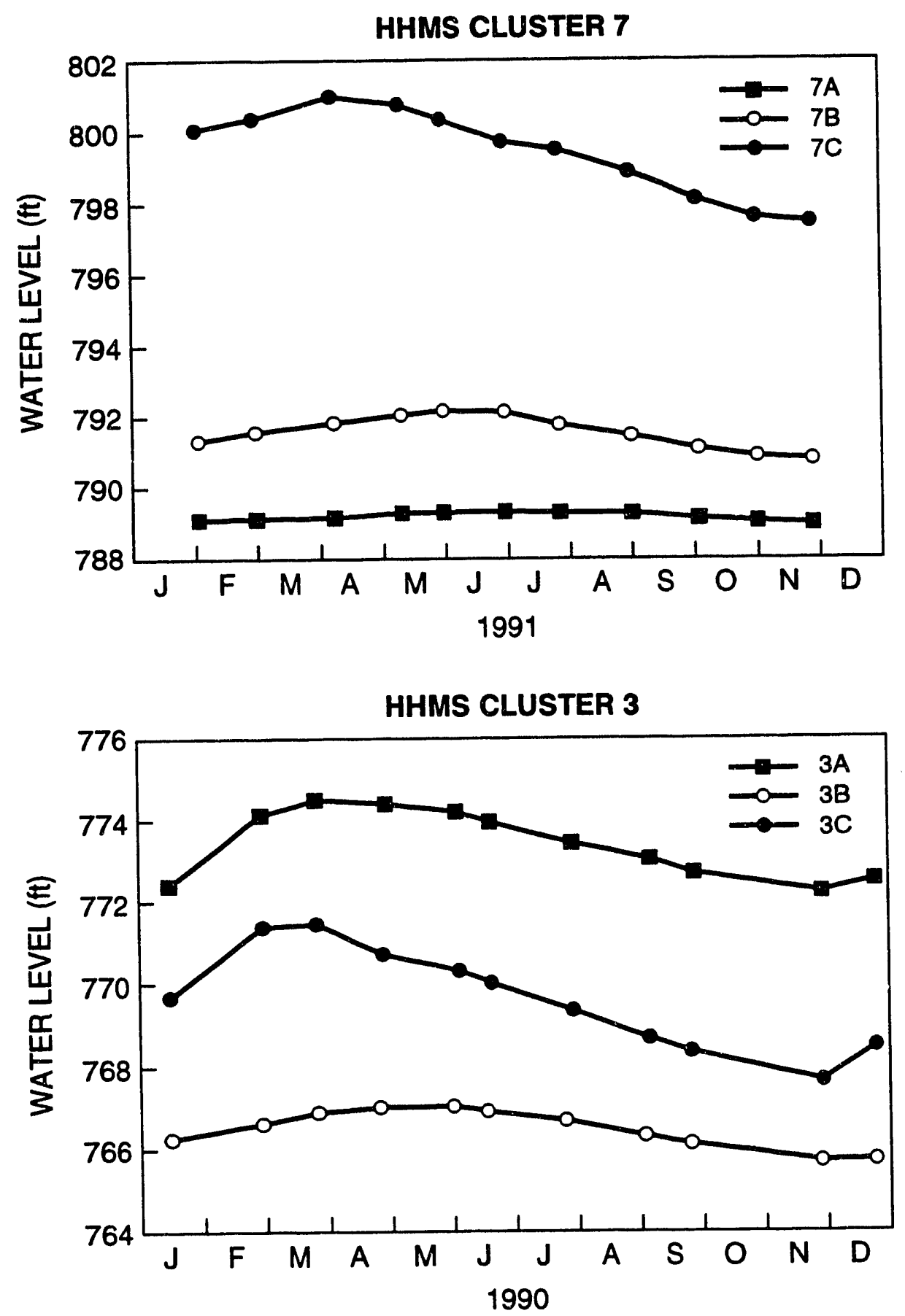

Fig. 6. Water level in HHMS clusters 7 (top) and 3 (bottom) during 1991. The open intervals in A, B, and C wells in cluster 3 are $116-122 \mathrm{~m}(380-400 \mathrm{ft}), 58-65 \mathrm{~m}(190-212 \mathrm{ft})$ and 19-25 $\mathrm{m}(62-81 \mathrm{ft})$. The open interval in A, B and $C$ wells in cluster 7 is $116-122 \mathrm{~m} \mathrm{(380-}$ $400 \mathrm{ft}), 84-90 \mathrm{~m}(275-295 \mathrm{ft})$, and 48-54 m (158-178 ft). 

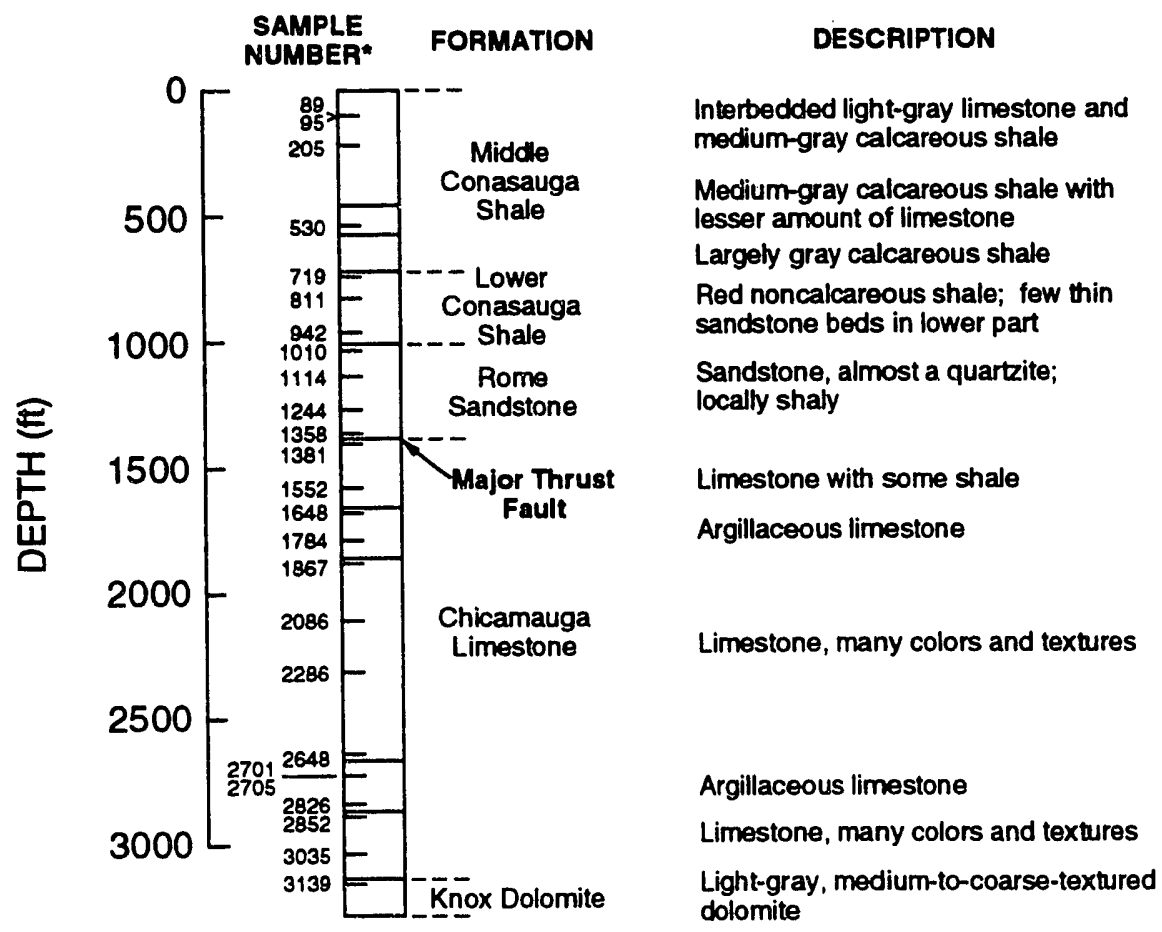

-Sample number also corresponds to depth in feet

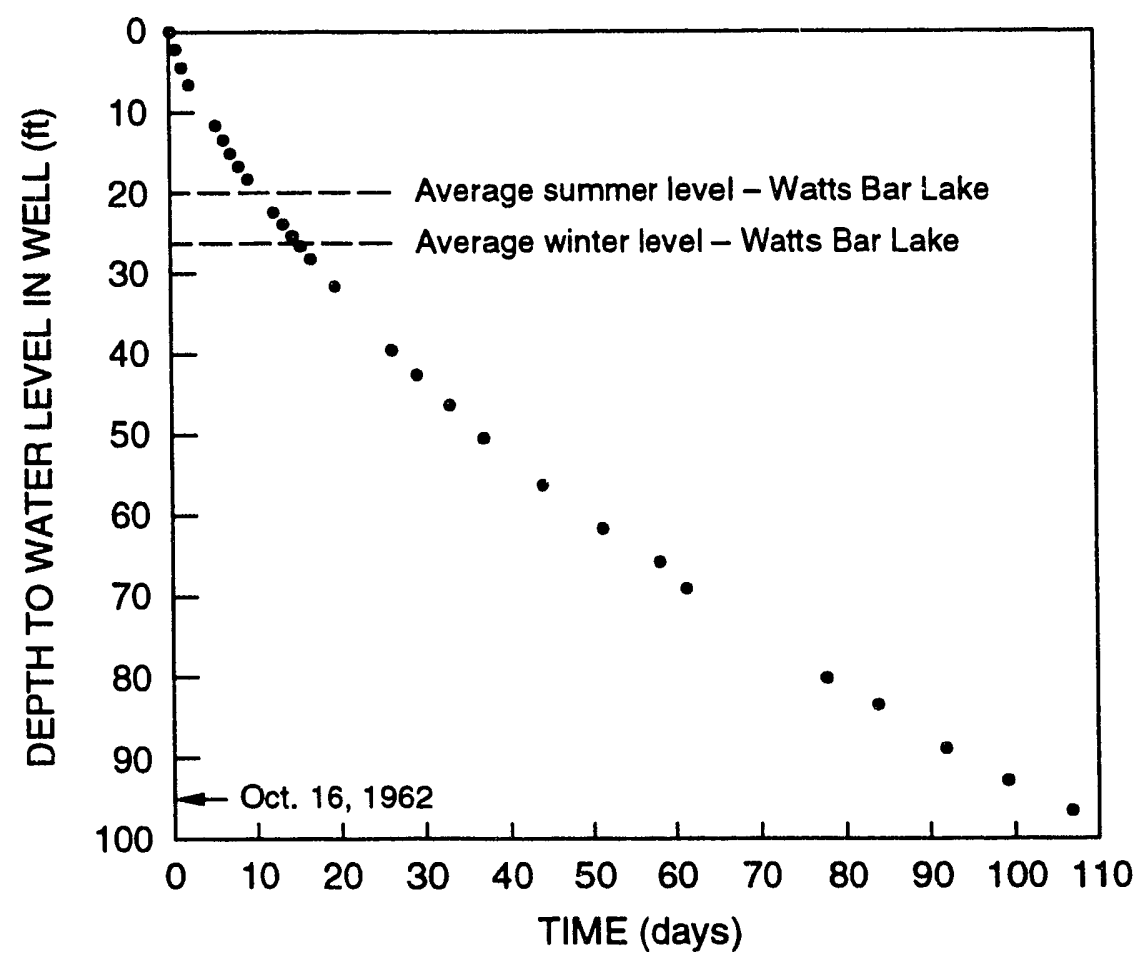

Fig. 7. General description of core from the Joy-1 well (top) and water level drop in its casing (bottom) (De Laguna et al. 1968). 
area (Fig. 7). It became evident that the water was being taken into rocks in the lower Chickamauga and upper Knox groups as the result of a lower hydraulic head in these formations (de Laguna et al. 1968). Both HHMS13 and Joy-1 were drilled through the Copper Creek thrust iault. If this fault acts as an impermeable boundary, the hydraulic head in the underlying formation may respond to the shallower hydraulic system at distance (which would have lower hydraulic head) rather than to the higher hydraulic head in the formations directly overlying the fault. "Soft, very fine grained and apparently very impermeable" shale was documerted in the Copper Creek fault crossed by the Joy-1 well (de Laguna et al. 1968, p. 20). However, the massive loss of circulation encountered during the drilling through the Copper Creek fault in Joy-2 (Haase et al. 1985) suggests that, at places, the fault has high hydraulic permeability and cannot function as a hydrological barrier.

The degree of confinement of the deep system from the overlying unconfined freshwater system and the atmosphere was estimated from water level variation measurements. Confined groundwater that has little connection with the atmosphere displays minute pressure variations affected by earth tide and barometric pressure variations (Bredehoeft 1967; Geiske and de Vries 1985; Jacob 1940; van der Kamp and Gale 1983). To date, the bottoms of five deep wells in the ORR have been packed (Appendix A). The water pressure in the packed interval was monitored with high-resolution ( 5 and 2.5 psig) pressure transducers located far above the packed interval, a few feet below the water level of the packed interval. This configuration facilitated the measurement of minute $[0.003-\mathrm{m}(0.01-\mathrm{ft})]$ water level variations.

Figure 8 illustrates the pressure variations observed in each well during 1 month, suggesting that the confinement of the deep system is effective regardless of the lithology or the stratigraphy involved. The smallest head variations, which amounted to $<0.03 \mathrm{~m}(0.1 \mathrm{ft})$, were observed in the WOL-2 well completed in the Rogersville shale, Conasauga Group. Daily variations of $0.15 \mathrm{~m}(0.5 \mathrm{ft})$, with some response to barometric pressure variations and rain events, were documented in the coreholes $\mathrm{CH}-6$ and $\mathrm{CH}-9$ that were completed in the Chickamauga Group (limestone). The most responsive well, WCR-2, was completed in the Copper Ridge Dolomite, Knox Group [packed interval at 155 to $163 \mathrm{~m}$ to (510 to $535 \mathrm{ft}$ ) below land surface], and it displays both large daily fluctuations [exceeding $0.3 \mathrm{~m}(1 \mathrm{ft})$ on some days] and longer-term fluctuations [ $>1.2 \mathrm{~m}(4 \mathrm{ft})]$. The longer-term fluctuations may either (1) reflect barometric pressure variations or (2) be direct responses to recharge during rain events (June 4-6,1992) followed by water level depletion during the subsequent period when only very small precipitation events occurred. The Copper Ridge Dolomite is known to be a karst aquifer in shallower zones, and this feature may also be relevant at greater depths.

With these observations in mind, it should be noted that wells in unconfined aquitards that have very small porosity values (or very large aquifer saturated thickness) may also display small water level fluctuations in response to earth tides (Bredehoeft 1967). In fact, Richardson (1956) reported tidal fluctuations in a well at Oak Ridge that penetrated an unconfined aquifer and had a semidiurnal tidal fluctuation with an amplitude of $\sim 2 \mathrm{~cm}$ $(0.06 \mathrm{ft})$. The tidal response is generally less efficient than in a well that taps confined systems; thus, the larger values observed in most of the packed wells are considered to represent a confined system. 


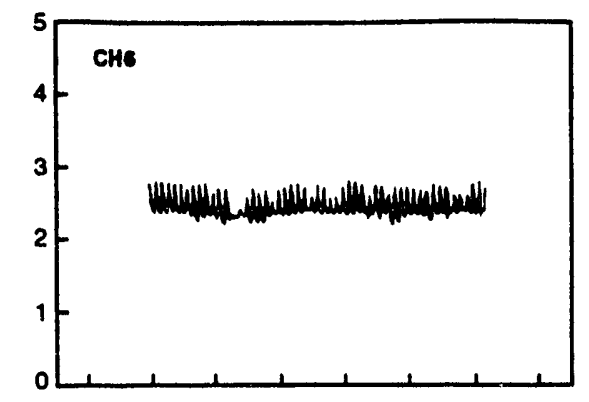

ORNL-DWG 92M-15925
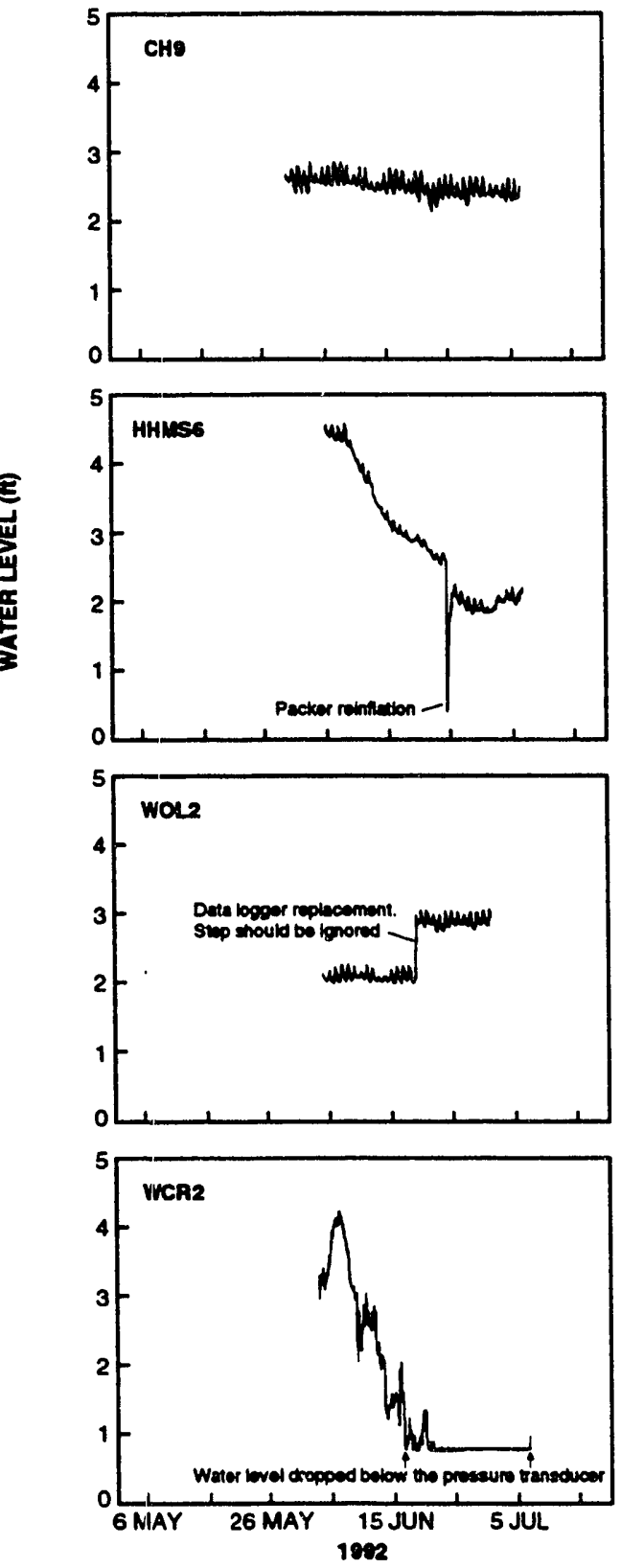

Fig. 8. Water level variations in the packed intervals of five deep wells (for wells information see Appendix A). 
Water level variations in deep wells [ $>45 \mathrm{~m}(150 \mathrm{ft})]$ cased close to their bottoms may imply seasonal or event-based recharge. Water levels in the HHMS wells were monitored continuously during the period when the wells were still recovering and monthly for several more years. The monthly monitoring allowed the detection of only seasonal variation. Whereas groundwater levels in some of these deep wells do not display any temporal variations, groundwater levels in other wells suggest seasonal recharge (Fig. 6). Note that the water levels at wells displaying seasonal variations also are higher than the water levels documented at nearby shallower wells. Hence, the seasonal response could not be attributed to direct percolation of water from above and may be related to recharge from a more distant source. Weekly monitoring of water levels to identify event-based recharge is planned in selected wells.

It is believed that the freshwater/brine interface represents the lower boundary of the actively flushed zone, the position of which is controlled by fracture density, aperture, and interconnectedness (Solomon et al. 1992). Electrical resistivity logs in open coreholes display a relatively sharp transition zone in some boreholes and a gradual salinity increase in others (Fig. 9). In coreholes tapping the Chickamauga Limestone, the depth of the interface varies from 53 to $110 \mathrm{~m}$ (174 to $360 \mathrm{ft}$ ) (coreholes $1,2,3,5,6$, and 9). Periodic logging may reveal seasonal variations of the interface position and will help to clarify whether it is controlled by fracture density or head variations in the deep and shallow systems. Monthly logging of electrical conductivity at the interface will be carried out during 1993 in three wells (CH-5, $\mathrm{CH}-143$, and $\mathrm{CH}-1$, completed in the Chickamauga, Knox, and Conasauga groups, respectively), in addition to continuous logging for several months in two wells (CH-6 and $\mathrm{CH}-143$, completed in the Chickamauga and Knox groups, respectively).

\subsection{HYDRAULIC PARAMETERS}

A variety of borehole techniques was used to measure the hydraulic conductivity of the rocks, including packer, slug, and slow-recovery tests (Dreier and Toran 1989; King et al. 1988; Solomon et al. 1992). These tests were run primarily in the Conasauga aquitards (east and west Bear Creek Valley), but some were also run in the Chickamauga aquitard (Bethel Valley) (Environmental Restoration Program 1992). Estimated values of hydraulic conductivity obtained by using these techniques ranged from $10^{-5}$ to $10^{-9} \mathrm{~cm} / \mathrm{s}$, with mean values of $10^{-7}$ or $10^{-8}$ for most areas (Solomon et al. 1992). The porosity of the Conasauga and Chickamauga groups was estimated by using core analyses. Values ranged from 0.2 to $0.4 \%$ (Solomon et al. 1992). The low permeability values may reflect the hydraulic properties of the unfractured matrix. These properties are difficult to measure in fracture zones, but the few available measurements suggest the presence of locally increased fracture density resulting in potentially enhanced flow. Although the number of permeable fractures generally decreases with depth, their presence at depth was documented in many of the deep coreholes and wells (Haase et al. 1987a; King et al. 1988). In a single listing of wells in the Oak Ridge Y-12 Plant area (King et al. 1991), the presence of fractures at depths $>50 \mathrm{~m}$ (164 ft) was documented during the drilling of 13 boreholes (GW-161, 165, 214, 230, 232, 293, 303, 344, 623, 625, 627, 628 , and 629). Because many of the boreholes included in that report were not described in detail, this list is probably incomplete. Of the 15 wells drilled to the Maynardville Formation during the last 2 years, 12 had water-producing fractures at depths $>50 \mathrm{~m}(164 \mathrm{ft}$ ) (Shevenell et al. 1992). Fractures were assumed to account for increases in permeability, as well as pressure, temperature, and hydrochemical anomalies and the presence of contaminants in 

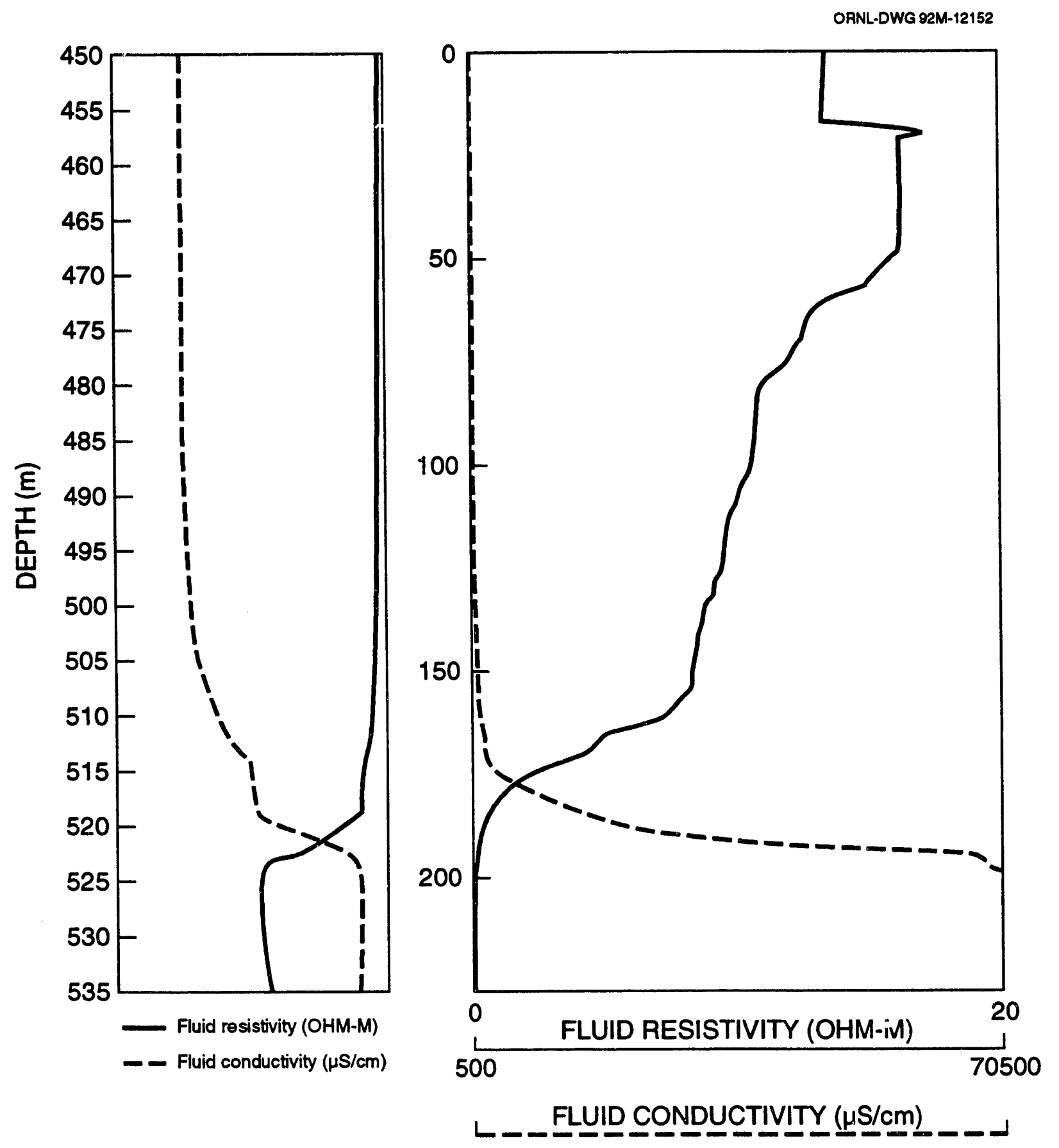

Fig. 9. Resistivity logs from WCR-2 well (open to the Knox Group) (left) and from CH-5 well (open to the Chickamauga Group) (right). 
many boreholes (HHMS8a, HHMS3a, GW-134, GW-135, GW-625, GW-628, and GW-629 wells) (Dreier and Toran 1989; Dreier et al. 1991; Haase and King 1990; King et al. 1988).

These observations suggest that the characterization of the deep system using the extremely low estimates of hydraulic conductivity may be an oversimplification. Groundwater flow and solute transport in this zone are greatly affected by the discontinuities in the lowpermeability environment, and those features may occur more abundantly than previously assumed, especially in karst-affected formations in the Knox Group. This conclusion calls for parameter-estimation techniques that are more suitable for fractured media than the techniques previously practiced on the ORR. Borehole methods that use concentration gradients in space and time (Tsang et al. 1990; Ronen et al. 1986) or accurate flow-meter measurements in packed intervals (Moore and Young 1992) (Fig. 10) were designed specifically for dual-porosity, dual-permeability environments and, hence, are potentially more successful. A point-dilution experiment is suggested for two wells for FY 1994.

The storage coefficient of the deep system can be estimated by using pressure variations in response to barometric and tidal variations in the confined system. The relationships between tidal efficiency, barometric efficiency, and specific storage for a porous medium may be stated as

$$
\begin{aligned}
& \text { tidal efficiency }=\rho_{w} g \beta_{p} / S_{s}, \\
& \text { barometric efficiency }=\rho_{w} g n \beta_{w} / S_{s},
\end{aligned}
$$

where $\rho_{\mathrm{w}}$ is the water density, $\mathrm{g}$ is gravity, $\beta_{\mathrm{p}}$ is the vertical compressibility, $\mathrm{S}$ is the specific storage, $\mathrm{n}$ is the total porosity, and $\beta_{\mathrm{w}}$ is the fluid compressibility.

Because the sum of the barometric and tidal efficiencies is unity, the percentage of storage attributable to expansion of the water is the barometric efficiency and that attributed to compression of the matrix is the tidal efficiency. However, these relationships were developed for a porous medium, and their validity for a fractured medium has to be assessed.

\subsection{TEMPERATURE VARIATIONS}

Temperature anomalies recorded on temperature logs (Dreier and Toran 1989; Dreier et al. 1991) can be used effectively to identify fractures and groundwater conduits in boreholes with no cores. They are also useful in detecting vertical flow gradient where well clusters are unavailable. Temperature deflections in HHMS8a and HHMS3a wells showed an increase of 2 to $5^{\circ} \mathrm{F}$, which was thought to result from the influx of water that was transported from a deeper source [at least $150 \mathrm{~m}(500 \mathrm{ft})$ below the logging interval] along a fault zone (Dreier and Toran 1989).

One-time temperature logging in six Chickamauga coreholes showed a gradual increase of temperature with depth in some wells (top of Fig. 11) and suggests the deep penetration of cooler water from above in other wells (Fig. 11). Temperature logging will precede the packing of each borehole. 


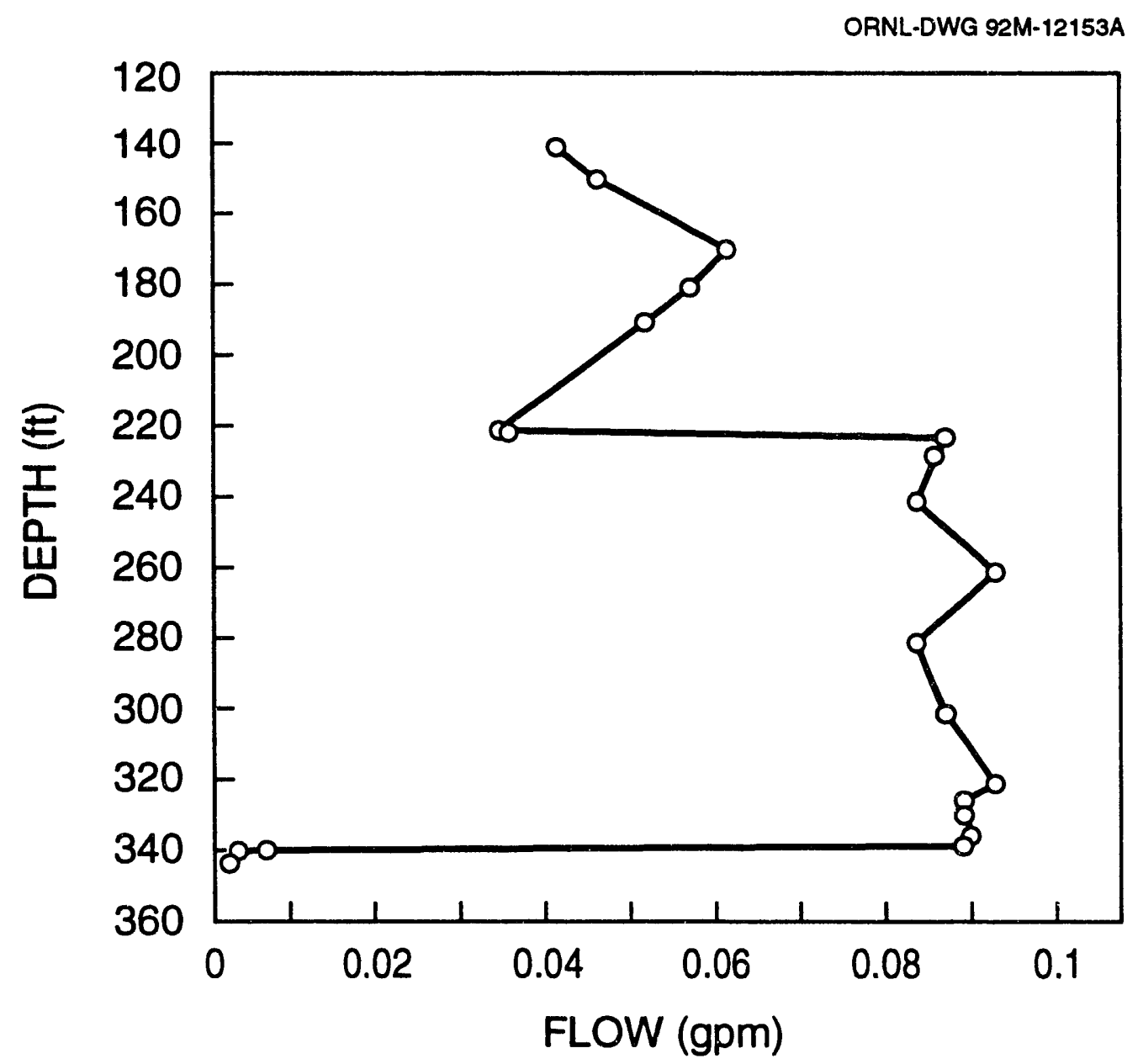

Fig. 10. Groundwater flux through fractures in CH-9 corehole. The flux was measured using a flow meter. The test was performed on November 15, 1991 (Moore and Young 1992). 

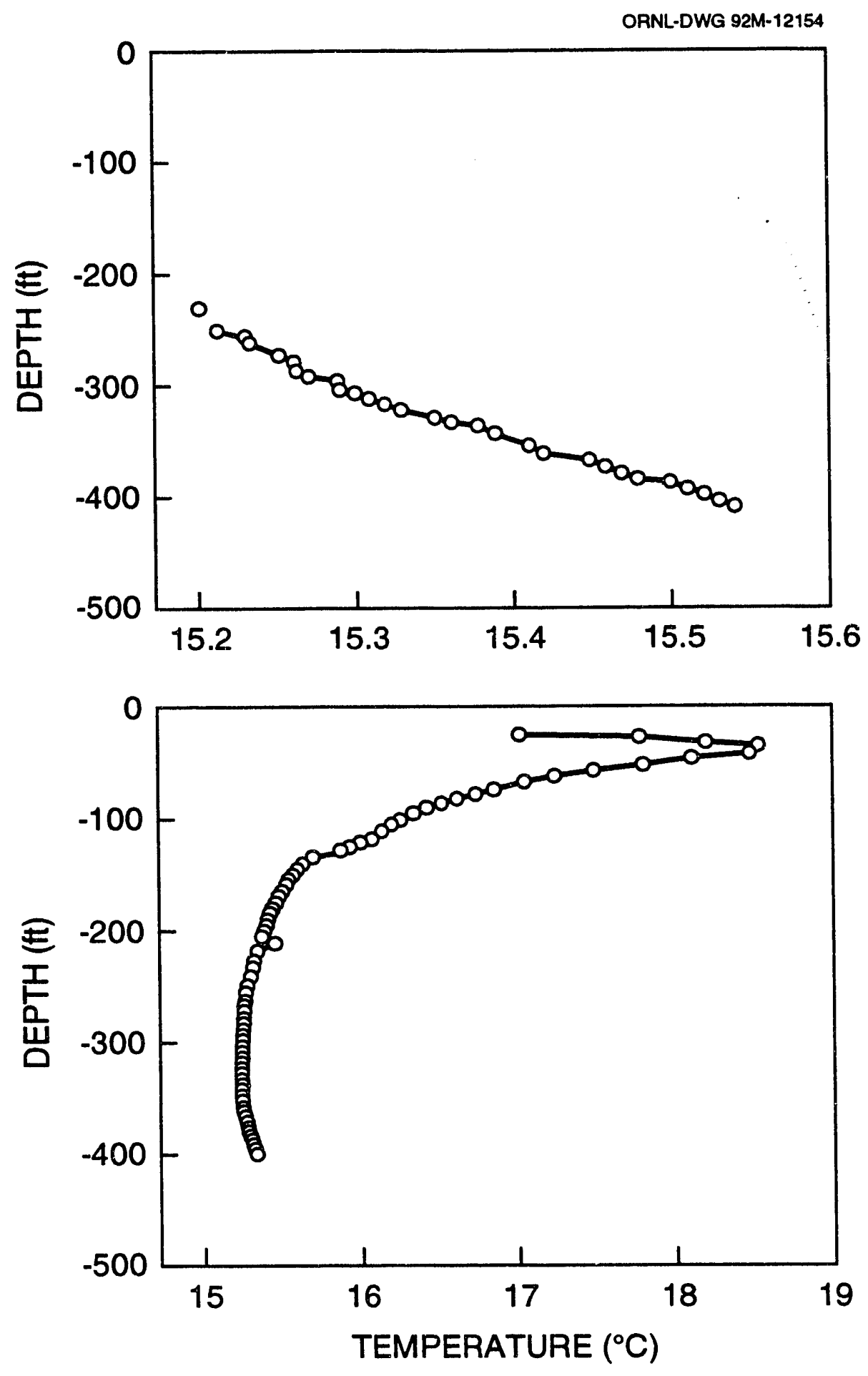

Fig. 11. Temperature logs from CH-6 (top) and CH-9 (bottom) wells (open in the Chickamauga Group). 
Periodic logging may help identify recharge-related temperature effects (Shuster and White 1971; Winslow et al. 1965) and assess the relationships between the shallow and the deep systems. During 1993, monthly temperature logging is being performed in three wells ( $\mathrm{CH}-5, \mathrm{CH}-143$, and $\mathrm{CH}-1$, completed in the Chickamauga, Knox, and Conasauga groups, respectively), in addition to continuous logging for several months in two other wells (CH-6 and $\mathrm{CH}-143$, completed in the Chickamauga and Knox groups, respectively).

\subsection{CHEMICAL AND ISOTOPIC COMPOSITION}

The chemical and isotopic composition of groundwater is used to (1) infer hydraulic connection between different stratigraphic and lithologic rock units on the basis of chemical similarity or, conversely, hydraulic disconnection on grounds of chemical differences; (2) identify potential recharge and discharge zones, assuming that grouncwater near the recharge zone is fresher and younger than that downgradient; and (3) relate groundwater to specific lithology, thus implying likely flow paths. Following the packing and purging of a short saline interval, groundwater will be sampled from all accessible deep wells. The first five wells (CH-6, CH-9, WOL-2, HHMS6a, and WCR-2) were purged from July 1992 to February 1993.

\subsubsection{Brine Occurrence}

The occurrence of brine is not unique to the ORR; salt beds and brine occur throughout the Appalachian Region. Beds of rock salt of Silurian age underlie southern New York, much of western Pennsylvania, eastern Ohio, and northern West Virginia. Rock salt of Mississippian age is found in southwestern Virginia. In addition, natural brine is found in wells in strata ranging in age from Cambrian to Pennsylvanian in Ohio, Pennsylvania, West Virginia, Kentucky, and Tennessee (Kreiger et al. 1957).

The Silurian salt beds (consisting primarily of halite) are part of a sequence of shale, dolomite, and evaporites. This sequence is referred to as the Salina Group, and it occurs in New York and in most of the subsurfice in Ohio and Pennsylvania. Southeastward and southwestward, rocks of the Salina Group grade into limestone and shale; in the Valley and Ridge province, equivalent rocks called the Tonoloway Limestone, Wills Creek Shale, and McKenzie Formation do not include salt beds. In Ohio, salt beds thin and disappear but reappear as a thick sequence in the Great Lakis Region (Kreiger et al. 1957).

Brine-bearing sands occur throughout the Pennsylvanian System, but the most important are the Salt Sand and Maxton Sand in the Pottsville Formation. The most important brineproducing sand in the Mississippian System is the Big Injun Sand, a part of the Pocono Formation. Many arilling logs from oil-producing Mississippian formations in the Cumberland Plateau, Tennessee, also report the occurrence of brine at depth (Milhous 1959). The Upper Devonian shale sequence contains many sand beds that yield brines in Pennsylvania and West Virginia. The Oriskany Sandstone of the Lower Devonian contains concentrated brine in Pennsylvania, Maryland, Ohio, and West Virginia. Brine also occurs in the limestone sequence of Silurian and Devonian age in Kentucky (referred to as coniferous by drillers). In Kentucky, below the Silurian Salina Group, lies the brine-bearing Newburg Sand. Brines have been recorded in the Ordovician Trenton Formation. St. Peter Sandstone, and Knox dolomite (Upper Cambrian and Lower Ordovician). 


\subsubsection{Discharge Points}

Potential outlets of the brine may be saline springs or upward leakage into more pernneable zones. Hundreds of springs issue inside the ORR and along its boundaries. Topographic maps dated to 1940 , before the Tennessee Valley Authority constructed dams on the Clinch River, show springs that were later flooded by the higher water stage. It became obvious that surveying each of these springs called for a separate study; consequently, a year-long spring survey at two transects (along Chestnut Ridge and across strike) began in the spring of 1992 to identify these outlets. The survey includes the measurement of electrical conductivity, temperature, and dissolved oxygen of all the springs along these transects and biannual sampling of selected springs for chemical and isotopic analyses. By July 1992, 83 springs had been located and measured for field parameters in an area of about 2 to 3 mile ${ }^{2}$. No temperature anomalies were observed, and only a few springs had electrical conductivity higher than $0.6 \mathrm{mmho} / \mathrm{cm}$ or anoxic water (Steven Jones, Oak Ridge Y-12 Plant, personal communication. June 1992). Sampling at Oliver Spring, north of the ORR, which reportedly had high mineral content (Killbrew 1874), and at Sulphur Spring northeast of the ORR revealed chemically reduced water containing low salt concentration $(2.53$ and $0.89 \mathrm{mS} / \mathrm{m})$.

\subsubsection{Spatial Variations of Brine Concentrations}

Groundwater salinity in the deep system varies from a few thousand to over $200,000 \mathrm{ppm}$ TDS. These variations cannot ue tied to chemical evolution along a probable flow path. When sampling the deep wells rerealed only brackish water, it was generally assumed that, in that location, brine water is present at deeper, untapped zones (Dreier et al. 1991; Solomon et al. 1992). However, groundwater sampling in the monitoring wells surrounding the hydrofracture facility in Melton Valley resulted in large spatial variations in chemical composition in the same area, formations, and depth. DM1 and DM2 wells are located about $640 \mathrm{~m}(2100 \mathrm{ft})$ apart, and their uncased interval in the Rome Formation is similar [333 to $350 \mathrm{~m}$ (1092 to $1149 \mathrm{ft}$ ) and 330 to $389 \mathrm{~m}$ (1084 to $1275 \mathrm{ft}$ ), respectively]. Chloride concentrations in the sampled groundwater of the two wells differ by almost $40,000 \mathrm{ppm}$ (91,000 and 130,000 ppm, respectively) (Haase and Stow 1987).

The difference in groundwater salinity in these wells could be attributed to waste injection activities in the area. Chloride concentration of the waste did not exceed $5000 \mathrm{ppm}$ (Switek et al. 1987); therefore, the injected water could not contribute a considerable amount of salinity. Instead, the injected water cuuld dilute the original brine to an unknown extent. Whereas injected water reached the DM-1 and DM-2 wells (as evidenced by the presence of ${ }^{90} \mathrm{Sr}$ in their groundwater) and could account for the spatial salinity variations, similar salinity variations were also observed in the Rock Cover wells, where no contamination (hence, no dilution) was documented. The RC200S and RC280SW wells are located $<122 \mathrm{~m}$ (400 ft) apart, and the same open interval [top at 150 to $180 \mathrm{~m} \mathrm{(490} \mathrm{to} 590 \mathrm{ft}$ ) and bottom at 180 to $210 \mathrm{~m} \mathrm{(590} \mathrm{to} 689 \mathrm{ft}$ )] and the same formations (Rutledge limestone and Rogersville shale) were tapped. Chloride concentrations observed in RC200S and RC280SW were 71,000 and 120,000 ppm, respectively, displaying a 49,000 ppm difference (Switek et al. 1987). Because the Rock Cover wells were sampled on three different occasions, the last preceded by the purging of the wells, these salinity variations appear to be real from the sampling point of view. If these variations are not related to analytical problems, they suggest the lack of spatial hydraulic connection and circulation even on a local scale. Because these salinity variations 
result in significantly different values of water density and viscosity (1.08153 and 1.19170 $\mathrm{mg} / \mathrm{cm}^{3}$ and 0.96 and $1.12 \mathrm{cp}$, respectively, at $30^{\circ} \mathrm{C}$ ), they must be accounted for in any groundwater flow model of this system.

\subsubsection{Temporal Variations of Brine Concentrations}

In addition to spatial salinity variations, temporal changes were also observed at wells that were sampled several times. The difference in chloride concentrations between two subsequent samplings at the same depth amounted to $92,000,31,600$, and 19,000 ppm in RC280SW, RC200S, and RC200E wells, respectively (Switek et al. 1987). The observed salinity variations were reported to be related to groundwater movement within the strata surrounding the wells (Switek et al. 1987). This conclusion, however, contradicts the large spatial variations among these wells, which suggest restricted groundwater movement to small, disconnected enclaves. It is hoped that packing and purging these wells before they are sampled for chemical and isotopic analyses will resolve some of these contradictory observations.

\subsubsection{Genesis of the Brine}

The origin of the brine at depth in various study areas in the Appalachian Region has been discussed extensively by previous researchers, and there seems to be a general agreement that the brine is mainly derived from ancient seawater entrapped during sedimentation (Davis 1991; Price et al. 1937; Rose and Dresel 1990; Stout et al. 1932; Toran and Saunders, 1992). Rose and Dresel (1990) observed that the most-concentrated brines in western Pennsylvania closely approximate the composition of a seawater that has been evaporated well into the stage of halite precipitation. The composition of less-concentrated samples is explained by dilution of the concentrated brine with freshwater or seawater. The fact that the most-concentrated brines in western Pennsylvania approximate highly evaporated seawater strongly suggests, according to Rose and Dresel (1990), that a major component of the brines and the major source of salts was residual pore fluid from evaporite (salt) deposits. The major evaporite body in this region is the Silurian Salina Formation, which contains large thicknesses of halite and anhydrite. These deposits suggest that the original pore fluids had a density much higher than seawater or other connate fluids, and the original pore fluids are inferred to have displaced or mixed with less-dense conate fluids in the underlying Paleozoic sediments. Compaction during the deposition of Paleozoic sediments and tectonic stresses during the late Paleozoic era may have caused the brine to migrate into the overlying formations, displacing or mixing with the original pore fluids in those units. The net result is that residual evaporite brine and its diluted equivalents occupy most or all of the pore space in the deeper parts of the sedimentary sequence of west Pennsylvania. According to Poth (1962) and Davis (1991), the compaction and stresses [mentioned by Rose and Dresel (1990)] resulted in the ultrafiltration that produced the brine.

According to Toran and Saunders (1992), the brine encountered on the ORR might have occupied a structurally higher position in the past and is continuously being flushed out by the fresh groundwater system. Where flushing becomes inefficient, brine can be found. All studies support the concept that the deep system that contains the brine is hydraulically inactive. It has been recognized (Price et al. 1937), however, that there are many instances in which Appalachian brines seem to include, along with waters of marine origin, greater or lesser proportions of groundwater of meteoric source. 
Although all these studies suggest an extremely long residence time for the brine [Rose and Dresel (1990) proposed an age of 300 million years], another alternative-the solution of halite by modern water-needs to be considered for the ORR. Halite crystals were found in the Rome Formation (Lemiszki 1992; Samman 1975), and they may account for the high salt content of the brine. If this explanation is viable, brine can form as a result of actively circulating groundwater that dissolves halite crystals.

Age indicators such as tritium and ${ }^{14} \mathrm{C}$ imply the residence time for groundwater and are used, therefore, to assess the potential for active groundwater circulation. Because brine samples for tritium and ${ }^{14} \mathrm{C}$ have not yet been analyzed, the two alternatives offered as explanation for the brine origin can be evaluated only by using the very few available analyses of ${ }^{18} \mathrm{O}$ and deuterium and ion ratios. Figure 12 displays the few isotope analyses made on samples from the HHMS2a, HHMS5a, and HHMS6a. Two of these samples deviate from the global meteoric line (Craig 1961), suggesting potential evaporation of meteoric water. (The local meteoric line for the ORR is currently being established through a year-long sampling of precipitation for ${ }^{18} \mathrm{O}$ and deuterium in the Walker Branch Watershed.) Note that the chloride content of these samples is relatively low and did not exceed $9000 \mathrm{ppm}$. Evidently, these samples are the products of mixing freshwater and brine; the brine end member may or may not show a higher degree of evaporation than the mixed water. Three analyses of brine sampled during this study from oil and gas wells outside the reservation [tapping the Knox Group and the Monteagle Limestone (Mississippian)] (Appendix B) show an increased deviation from the meteoric line, suggesting further evaporation.

To better assess the origin of the brine (until more isotopic data become available), its composition may be compared with the chemical composition of brines from oil and gas wells in nearby areas in Tennessee and with brines from adjacent states such as West Virginia, Kentucky, Ohio, Pennsylvania, or Alabama. Data were searched in state agencies, such as the Tennessee Division of Geology and the Tennessee Department of Health and Environment; in federal agencies, such as the U.S. Geological Survey, Nashville; and in commercial data bases operated by Petroleum Information and Dwite. Only eight chemical analyses from oil and gas wells were available for Tennessee (E. F. Holliday, U.S. Geological Survey, Nashville Tennessee, unpublished data). Therefore, several oil and gas wells were sampled near the ORR and on the Cumberland Plateau for chemical and isotopic analyses. Hundreds of brine analyses from the adjacent states were processed for this purpose (Appendix B).

Ion ratios proved to be a more efficient means to check the two alternative theories for brine formation because of a larger pool of chemical analyses of saline water. Values of $\mathrm{Na}: \mathrm{Cl}$ (milliequivalents) for all the brine samples (Fig. 13) were $<1$ (the value expected for water that dissolved halite). In fact, for most samples the values were $<0.86$ (current meteoric water) and reached a minimum value of 0.46 . This ratio decreases with increasing salinity. The excessive chloride concentrations are balanced by high concentrations of $\mathrm{Ca}$, as $\mathrm{SO}_{4}$ and $\mathrm{HCO}_{3}$ concentrations are insignificant. Note, however, that values of the $\mathrm{Na}: \mathrm{Cl}$ in brines from adjacent states where halite beds are abundant have similar values ( 0.6 to 0.7$)$ (Appendix $B$ ).

Values of $\mathrm{Br}: \mathrm{Cl}$ (by weight) in the ORR (Fig. 14) ranged from $69 \times 10^{-4}$ to $140 \times 10^{-4}$, orders of magnitude higher than values typical for halite dissolution, $4 \times 10^{-4}$ (Richter and Kreitler 1986; Whittemore and Pollock 1979). Values of $\mathrm{Br}: \mathrm{Cl}$ (by weight) increased with salinity. High values were also observed in brines from adjacent states (Appendix B). 


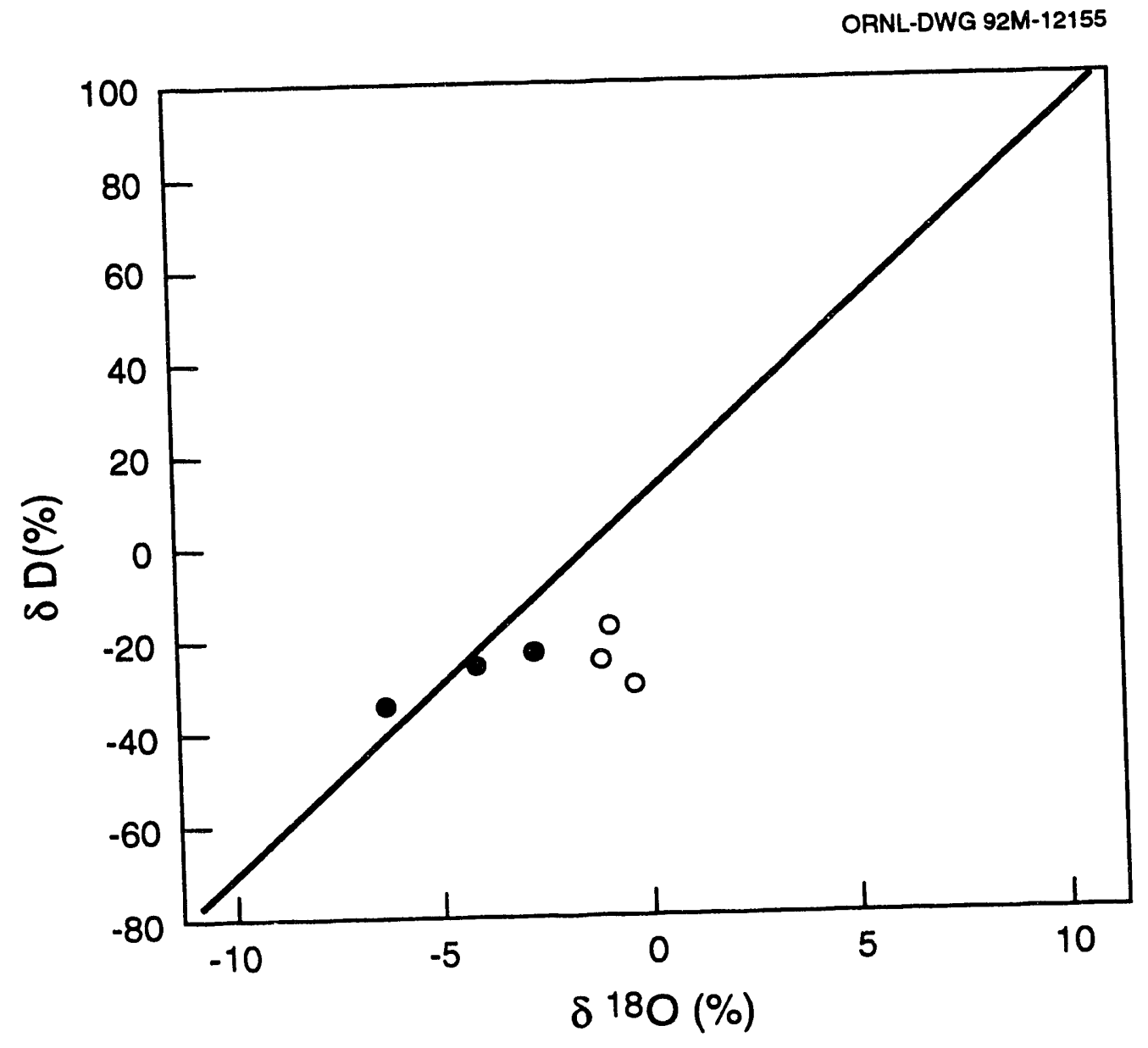

Fig. 12 Oxygen-18 and deuterium data from HHMS 2a, 5a, and 6a, where saline water was found (full circles) and from oil and gas wells outside the reservation (open circles). For HHMS wells location see Fig. 1. For oil and gas wells information, see Appendix C. The plotted line is the world meteoric water line (Craig 1961). 


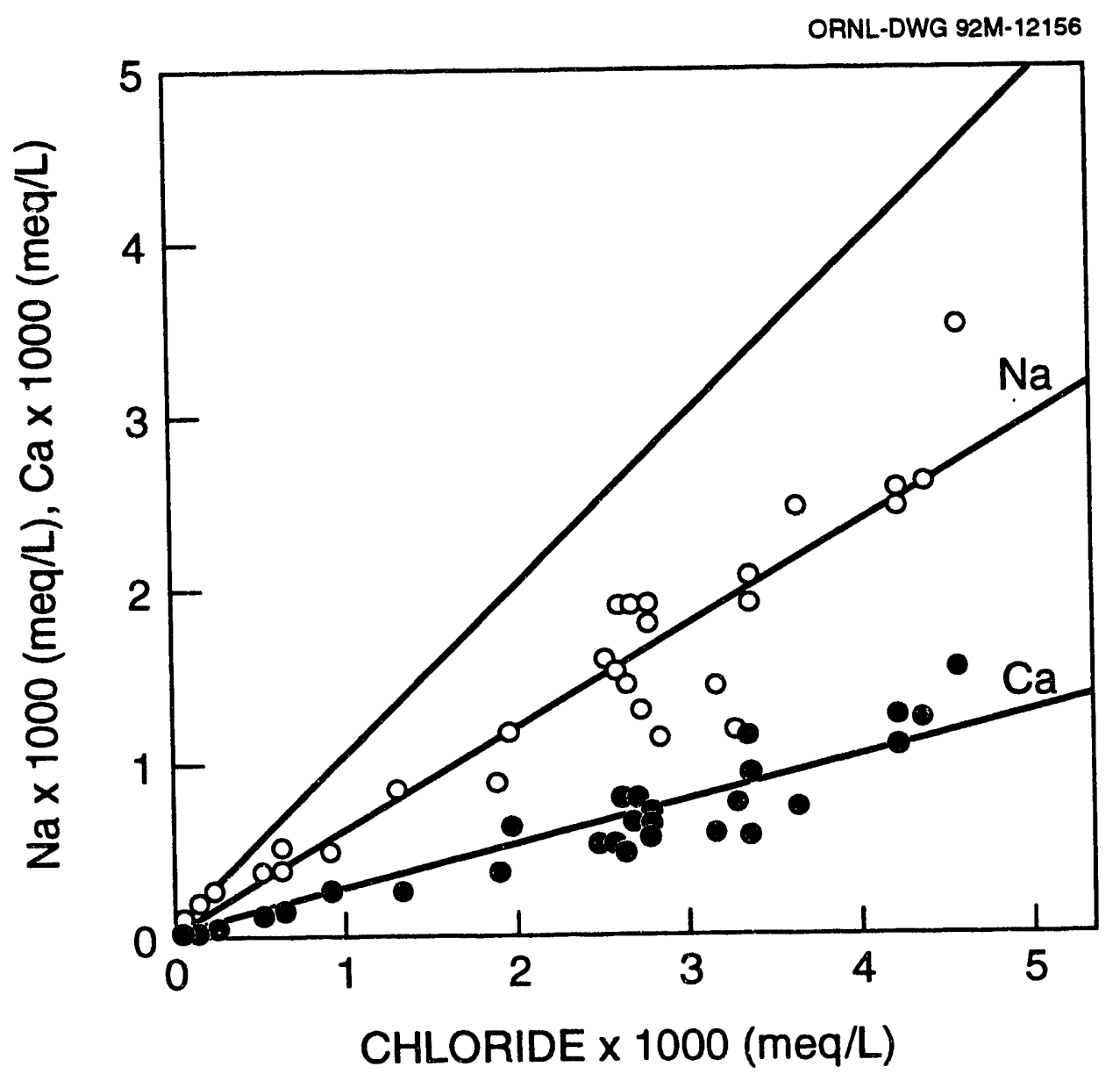

Fig. 13. Na:Cl (open circles) and $\mathrm{Ca}: \mathrm{Cl}$ (full circles) ratios for the deep brine, ORR. Sources: Chemical analyses, L. E. Toran (ORNL, personal communication to Ronit Nativ, 1992); rock cover wells, Switek et al. (1987); deep monitoring, Haase and Stow (1987); and unpublished data from WOL-1 and WOL-2 wells. 


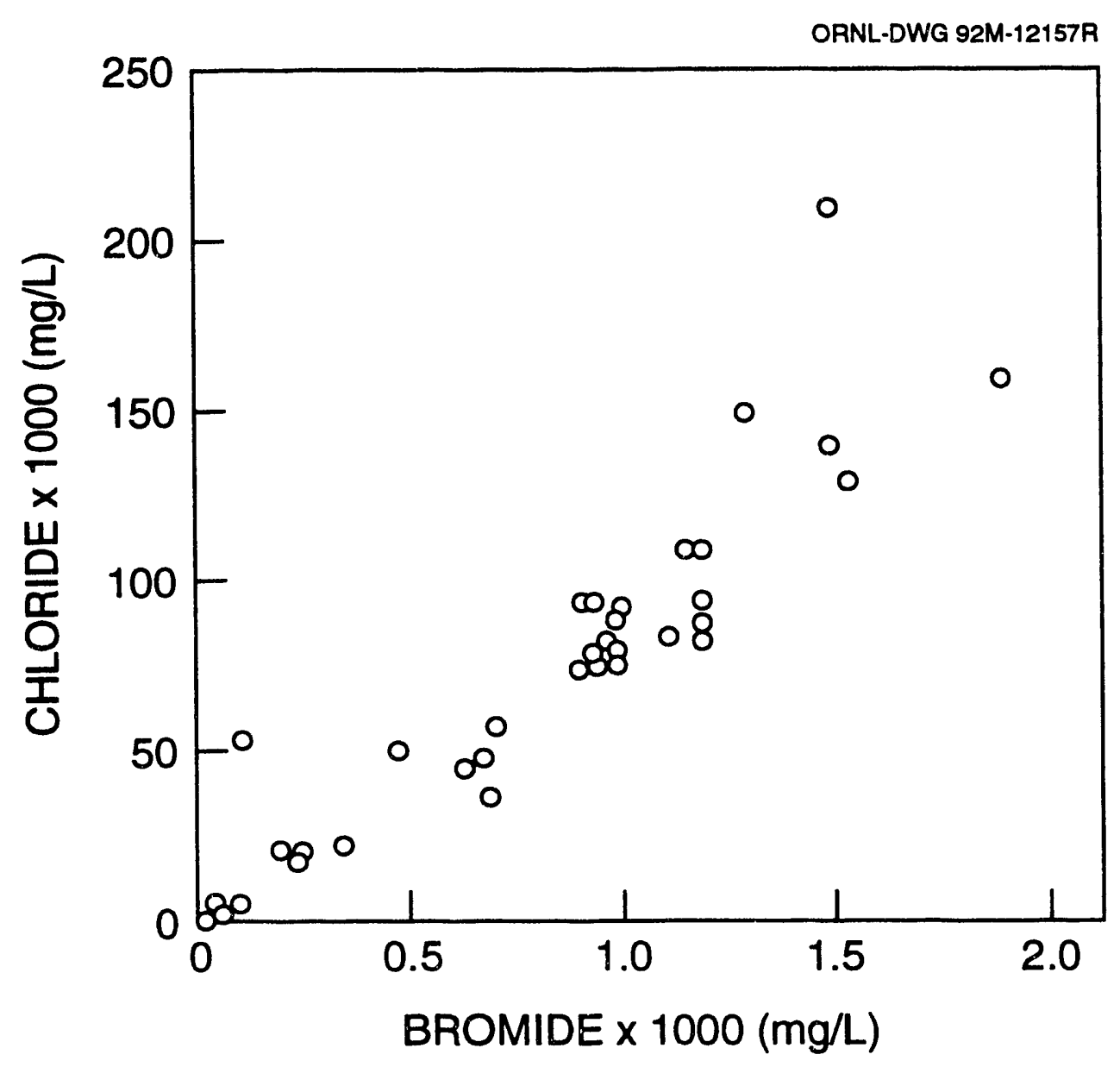

Fig. 14. Br:Cl ratio for the deep brine Sources: Chemical analyses, L. E. Toran (ORNL, personal communication to Ronit Nativ, 1992); rock cover wells, Switek et al. (1987); deep monitoring, Haase and Stow (1987); and unpublished data from WOL-1 and WOL-2 wells. 
Values of $\mathrm{Ca}: \mathrm{Na}$ (milliequivalents) ranged from 0.018 to 0.6 and increased with increasing salinity. The brine end member (as exemplified by groundwater samples from the Rock Cover and $\mathrm{DM}$ wells) is $\mathrm{Ca}-\mathrm{Cl}_{2}$ as suggested by the ion ratio $\mathrm{Ca} /\left(\mathrm{SO}_{4}+\mathrm{HCO}_{3}\right)>1$.

On the basis of these preliminary results, it appears that the brine did not originate from a halite solution created by recent water. Instead, it represents a residuum of original saline water that underwent the extensive evaporation (and the possible precipitation of halite) typical of oil-field brines. Hydrocarbons found in some ORR deep wells completed in the Chickamauga Group ( $\mathrm{CH}-4$ and $\mathrm{CH}-5$ ) and in the Knox Group (Joy-2) support this suggestion.

\subsubsection{Geochemical Modeling}

Geochemical modeling can be used to assess equilibrium between (1) the rock matrix and secondary mineralization and (2) the contained fluids. In the absence of highly soluble minerals, chemical and isotopic equilibrium between the rock minerals and their contained fluids may be an indicator of long residence time. Using the EQ6/EQ3 speciation model, Haase et al. (1987b) found that saline water in the Rome Formation and in the lower Conasauga Group is saturated with carbonates (calcite, dolomite, strontianite, and smithsonite) as well as with some sulfate minerals (barite and celestite) and aluminosilicates. In Bear Creek Valley, water in the Maynardville and Maryville limestone was also saturated with carbonate but undersaturated with gypsum, when evaluated by using the SOLMINEQ.88 (Toran and Saunders, in preparation) and WATEQF (Chapman-Bailey and Lee 1991) models. Isotopic composition of secondary mineralization in fractures may be indicative of current recharge or equilibrium between the rock matrix, secondary filling of fractures, and groundwater. Tritium in $\mathrm{CaSO}_{4} \cdot 2 \mathrm{H}_{2} \mathrm{O},{ }^{13} \mathrm{C}$, and ${ }^{18} \mathrm{O}$ in calcite are suitable tracers. This study has not yet begun. 


\section{CONCLUSIONS}

In this report, existing data from the deep system in the ORR were compiled and interpreted together with new field data collected during 1992. Accumulation of new data will continue during 1993. The following are some preliminary conclusions regarding the deep hydrogeological system.

There is some evidence to support the concept of stagnant brine at depth and its hydraulic disconnection from the overlying shallow, fresh, and active flow zone. The deep system is evidently confined, as was indicated by the daily pressure variations. The large spatial variations in the chemistry of its contained brine (observed in the Rock Cover wells) may support an extremely restricted flow in portions of the aquitard. The chemical equilibrium between the brine and so many of the host-rock minerals also indicates a long residence time and a very slow water flow (although chemical equilibrium with carbonate rocks can be reached rapidly). The ion ratios and stable isotopic composition of the brine resemble oil-field brines rather than halite-solution water, also suggesting a long residence time. Finally, defined outlets of the deep system could not be identified to date, also suggesting the absence of a driving flow mechanism.

Other evidence supports the potential for groundwater flow in the deep system. Fractures were observed at great depth in many cores, locally enhancing the permeability of the aquitards. Temperature anomalies are tied to some fractures, suggesting they may be hydraulically active, and actual flow through the fractures was measured in some coreholes with a flow meter. Fractures may account for some of the observed spatial variations in chemical composition that were mentioned in the previous paragraph by enhancing the flow and flushing of some portions of the aquitards. Seasonal water level variations were observed in some deep wells, suggesting active recharge (or at least rapid pressure response to a high-precipitation season) of the deep system. In the Knox aquifer, at a depth of $150 \mathrm{~m}$ $(500 \mathrm{ft})$, water level variations could even be tied to individual precipitation events. Temporal variations in brine chemistry were also related to active groundwater flow.

Similar (but not identical) values of the hydraulic head in the deep HHMS wells suggest the potential for lateral hydraulic continuity (as opposed to stagnant water), but the spatial variations in water chemistry documented in the nearby Rock Cover wells suggest the opposite. Similar water levels can mimic similar topography, without necessarily implying hydraulic connectivity (Toth 1963); however, this situation is more typical of unconfined aquifers than of the confined system in question. In addition, seasonal variations in water levels in some deep wells were observed where water levels in the deep wells were higher than water levels measured in nearby, shallow wells of the same clusters. This observation suggests that seasonal variations could not result from water percolation from the overlying shallow system. Instead, they probably reflect a lateral contribution from outcrops of unknown distance, requiring lateral hydraulic continuity between the outcrops and the wells. Spatial variations in salinity can thus be explained by (1) different, disconnected fracture nets feeding the Rock Cover wells with water that has distinct concentrations of solutes or (2) different fracture density allowing various degrees of flushing.

Vertical flow between the deep and the shallow hydrogeological system seems possible. The potential for upward flow from the deep hydrogeologic system into the shallow system 
is supported by a large array of observations, including temperature anomalies, water levels in some of the HHMS well clusters in the Conasauga Group, and water levels measured below and above packed intervals in coreholes in the Chickamauga and Knox groups. Potential for downward flow from the shallow to the deep system was documented in some of the HHMS wells completed in the Conasauga Group. Downward flow potential within the deep system was documented in Joy-1 and HHMS13 wells, completed in the Chickamauga/Knox groups and the Conasauga Group, respectively. The reason for the low pressure anomalies observed in these two wells is unclear.

On the basis of existing data, we offer the following description for the deep system that addresses most of these observations, including some apparent contradictions: The deep hydraulic system contains confined brine, whose residence time in the subsurface is probably very long. The brine is probably moving along active, open fractures at relatively high velocities; however, the total volume of water moving through these fractures is small. Groundwater discharge is probably through adjacent, more-permeable units where the brine is considerably diluted. Groundwater at great depth is currently recharged, but the amounts of modern water moving through the fracture network are probably small. The brine is probably not isolated from the overlying shallow system, and groundwater flow as well as solute transport between both systems takes place wherever pathways were naturally or artificially provided. The water volumes involved, however, are probably small. 


\section{REFERENCES}

Bredehoeft, J. D. 1967. Response of well-aquifer systems to earth tides. J. Geophys. Res. 72:3075-3087.

Brown, P. M., D. L. Brown, M. S. Reid, and O. B. Lloyd. 1979. Evaluation of the geologic and hydrologic factors related to the waste-storage potential of Mesozoic aquifers in the southern part of the Atlantic coastal plain, South Carolina and Georgia. U.S. Geological Survey Professional Paper 1088.

Chapman-Bailey, Z., and R. W. Lee. 1991. Hydrogeology and geochemistry in Bear Creek and Union valleys, near Oak Ridge, Tennessee. U.S. Geological Survey Water Resources Investigation Report 90-4008.

Clifford, M. J. 1973. Silurian rock salt of Ohio. State of Ohio Department of Natural Resources, Division of Geological Survey, Report of Investigation 90 . Columbus, Ohio.

Craig, H. 1961. Isotopic variations in meteoric waters. Science 133:1702-03.

Davis, N. S. 1991. The Oak Ridge Reservation hydrology and geology study, a preliminary evaluation, internal report.

De Laguna, W., T. Tamura, H. O. Weeren, E. G. Struxness, W. C. McClain, and R. C. Sexton. 1968. Engineering development of hydraulic fracturing as a method for permanent disposal of radioactive waste. ORNL-4259. Oak Ridge National Laboratory, Oak Ridge, Tennessee.

Dreier, R. B., and L. E. Toran. 1989. Hydrogeology of Melton Valley determined from head measuring station data. Environmental Science Division Publication No. 2836, ORNL/TM-11216. Oak Ridge National Laboratory, Oak Ridge, Tennessee.

Dreier, R. B., T. O. Early, and H. L. King. 1991. Groundwater studies at the Oak Ridge Y-12 Plant using multiport monitoring systems installed in coreholes. Proceedings of Focus Conference on Eastern Regional Groundwater Issues, NWWA, pp. 239-53.

Environmental Restoration Program. 1992. Site Characterization Summary Report for Waste Area Grouping 1 at the Oak Ridge National Laboratory, Oak Ridge, Tennessee. Draft (June 1992) ORNL/ER-131-V1, ORNL/ER/sub/87-99053/59/v1-v4. Oak Ridge National Laboratory, Oak Ridge, Tennessee.

Garven, G., and D. A. Sverjensky. 1989. Hydrogeology of regional flow systems associated with the formation of the Mississippi Valley-type ore deposits in the mid-continent.

Geiske, A, and J. J. de Vries. 1985. An analysis of earth-tide-induced groundwater flow in eastern Botswana. J. Hydrol. 82:211-32. 
Geraghty and Miller, Inc. 1987a. Preliminary evaluation of the hydrogeologic and waterquality data from phase 4 wells located in the Bear Creek Valley Waste Disposal Area for the period summer 1985-September 1986. Y/Sub/85-00206C/9. Oak Ridge Y-12 Plant, Oak Ridge, Tennessee.

Geraghty and Miller, Inc. 1987b. Ground-water quality assessment report for the burial grounds hazardous-water disposal unit at the Y-12 plant, 1986. Y/Sub/87-00206C/3. Oak Ridge Y-12 Plant, Oak Ridge, Tennessee.

Goodman, W. 1990. Medina brine circulation in a shallow flow system: the influence of stratigraphy and regional fracture. Geological Society of America Abstract and Programs 22(2): 20.

Haase. C. S. 1987. Geophysical data from boreholes DM1, DM2, DM3, and DM3A, new hydraulic fracturing facility, Oak Ridge National Laboratory, Oak Ridge, Tennessee. Environmental Science Division Publication No. 2836. ORNL/TM-9681. Oak Ridge National Laboratory, Oak Ridge, Tennessee.

Haase, C. S., G. E. Gillis, and H. L. King. 1987a. Fiscal year 1985 investigation drilling program at the Y-12 Plant, Oak Ridge Tennessee. ORNL/TM-9999. Oak Ridge National Laboratory, Oak Ridge, Tennessee.

Haase, C.S., and H. L. King. 1990. Report and preliminary assessment of the occurrence of dense, nonaqueous phase liquids in the Bear Creek Burial Grounds hazardous waste disposal unit and the Oak Ridge Y-12 Plant. Y/TS-629. Oak Ridge Y-12 Plant, Oak Ridge, Tennessee.

Haase, C. S., and S. H. Stow. 1987. Geochemistry of formation waters in the lower Conasauga Group at the new Hydrofracture facility: preliminary data from the deep monitoring (DM) wells. Environmental Science Division publication No. 2887. Oak Ridge National Laboratory, Oak Ridge, Tennessee.

Haase, C. S., K. L. Von Damm, and S. H. Stow. 1987b. Closure of the Oak Ridge National Laboratory Hydrofracture Facility: an opportunity to study the fate of radioactive wastes disposed of by subsurface injection. pp. 512-30. In: International Symposium on Class V Injection Well Technology, Underground Injection Practices Council, Inc.

Haase, C. S., E. C. Walls, and C. D. Farmer 1985. Stratigraphic and structural data for the Conasauga Group and the Rome Formation on the Copper Creek fault block near Oak Ridge, Tennessee: preliminary results from test borehole ORNL-JOY No. 2. Environmental Science Division Publication No. 2392. ORNL/TM-9159. Oak Ridge National Laboratory, Oak Ridge, Tennessee.

Heck, E. T., C. E. Hare, and H. A. Hoskins. 1964. Appalachian connate water. West Virginia Geological and Economic Survey Bulletin 28.

Jacob, C. E., 1940. On the flow of water in an elastic artesian aquifer. EOS Trans. AGU, 21:574-586. 
Killbrew. 1874. Resources of Tennessee. pp. 204, 271, and 455.

King, H. L., C. S. Haase, and B. K. Harrington. 1991. Updated subsurface data base for Bear Creek Valley, Chestnut Ridge, and parts of Bethel Valley on the U.S. Department of Energy Oak Ridge Reservation, Oak Ridge Y-12 Plant. Y/TS-735. Oak Ridge Y-12 Plant, Oak Ridge, Tennessee.

King, H. L., C. S. Haase, and E. C. Jordan. 1988. Summary of results and preliminary interpretation of hydrogeological packer testing in core holes GW-131 through GW-135 and CH-157 Oak Ridge Y-12 Plant. Y/TS-495, Oak Ridge Y-12 Plant, Oak Ridge, Tennessee.

Kreiger, R. A, J. L. Hatchett, and J. L. Poole. 1957. Preliminary survey of the saline-water resources of the United States. U.S. Geological Survey Water Supply Paper 1374.

Lamborn, R. E. 1952. Additional analyses of brines from Ohio. Geological Survey of Ohio Report of Investigation 11, Columbus, Ohio.

Lee, R. R., and R. H. Ketelle. 1987. Stratigraphic influence on deep groundwater flow in the Knox Group Copper Ridge dolomite on the west Chestnut Ridge site. ORNL/TM-10479. Oak Ridge National Laboratory, Oak Ridge, Tennessee.

Lemiszki, P. J. 1992. Geology of the Bethel Valley quadrangle-Part of the Department of Energy Oak Ridge Reservation in the southern Appalachian foreland fold-thrust belt and fracture mechanics modeling of extension fracture growth during basin subsidence and buckle folding. Ph.D. dissertation. University of Tennessee, Knoxville. 353 pp.

Milhous, H. C. 1959. Well logs in Tennessee. Division of Geology Bulletin 62. State of Tennessee Department of Conservation and Commerce, Nashville. 606 pp.

Moore, G. K 1988. Concepts of groundwater occurrence and flow near Oak Ridge National Laboratory, Tennessee. Environmental Science Division Publication No. 3218 ORNL/TM-10960. Oak Ridge National Laboratory, Oak Ridge, Tennessee.

Moore, G. K, and S. C. Young. 1992. Identification of groundwater-producing fractures by using an electromagnetic borehole flowmeter in monitoring wells on the Oak Ridge Reservation, Oak Ridge, Tennessee. ORNL/ER-91. Oak Ridge National Laboratory, Oak Ridge, Tennessee.

National Oceanic and Atmospheric Administration. 1984. Local climatological data annual summary with comparative data, Oak Ridge, Tennessee. National Climatic Data Center, Asheville, North Carolina.

Poth, C. W. 1962. The occurrence of brine in western Pennsylvania. Pennsylvania Geological Survey Bulletin M 47.

Price, P. H., C. E. Hare, J. B. McCue, and H. A. Hoskins. 1937. Salt brines of West Virginia. West Virginia Geological Survey, Vol. viii. 
Richardson, R. M. 1956. Tidal fluctuations of water level observed in wells in East Tennessee. Trans. Am. Geophys. Union: 37:461-62.

Richter, B. C., and C. W. Kreitler. 1986. Geochemistry of salt water beneath the Rolling Plains, north central Texas. Ground Water 24:735-42.

Ronen, D., M. Magaritz, and Y. Levy. 1986. A multilayer sampler for the study of detailed hydrochemical profiles in groundwater. Water Res. 20:311-15.

Rose, A. W., and P. E. Dresel. 1990. Deep brines in Pennsylvania. In: S. K. Majumdar, E. W. Miller and R. R. Parizek (eds.), Water Resources in Pennsylvania: Availability, Quality and Management. The Pennsylvania Academy of Science.

Samman, N. B. 1975. Sedimentation and stratigraphy of the Rome Formation in East Tennessee. Ph.D. dissertation. University of Tennessee, Knoxville. 337 pp.

Shevenell, L. A., R. B. Dreier, and K. W. Jago. 1992. Summary of fiscal years 1991 and 1992 construction, hydrologic and geologic data obtained from the Maynardville Limestone exit pathway monitoring program. Y/TS-814. Oak Ridge Y-12 Plant, Oak Ridge, Tennessee.

Shuster, E. T., and W. B. White. 1971. Seasonal fluctuations in the chemistry of limestone springs: a possible means for characterizing carbonate aquifers. J. Hydrol. 14:93-128.

Solomon, D. K, G. K. Moore, L. E. Toran, R. B. Dreier, and W. M. McMaster. 1992. A hydrologic framework for the Oak Ridge Reservation, status report. ORNL/TM-12053. Oak Ridge National Laboratory, Oak Ridge, Tennessee.

Startler, A. T., P. Bloss, and R. P. Zurawski. 1975. Subsurface information catalog of Tennessee 1866-1974. Tennessee Division of Geology Bulletin 76. Nashville, Tennessee.

Stout, W., R. E. Lamborn, and D. Schaaf. 1932. Brines of Ohio. Geological Survey of Ohio Bulletin 37. Columbus, Ohio.

Stow, S. H., and C. S. Haase. 1986. Subsurface disposal of liquid low-level radioactive wastes at Oak Ridge, Tennessee. In: Proceedings of the International Symposium on Underground Injection of Hazardous Wastes, New Orleans. National Water Well Association.

Switek, J., C. S. Haase, and H. S. Stow. 1987. Geochemistry of formation water in the lower Conasauga Group at the new hydrofracture facility: Preliminary data from the Rock Cover (RC) wells. Environmental Science Division publication No. 2863. ORNL/RAP-5. Oak Ridge National Laboratory, Oak Ridge, Tennessee.

Toran, L. E., and J. A. Saunders. 1992. Geochemical and groundwater flow modeling of multiport-instrumented coreholes (GW-131 through GW-135). Y/TS-875. Oak Ridge Y-12 Plant, Oak Ridge, Tennessee.

Toth, J. A 1963. A theoretical analysis of ground-water flow in small drainage basins. J. Geophysical Res. 68:4792-811. 
Tsang, C. F., P. Hufschmied, and F. V. Hale. 1990. Determination of fracture inflow parameters with a borehole fluid conductivity logging method. Water Resour. Res. 26:561-78.

van der Kamp, G., and J. E. Gale. 1983. Theory of earth tide and barometric effects in porous formations with compressible grains. Water Resour. Res. 19:538-44.

Whittemore, D. O., and L. M. Pollock. 1979. Determination of salinity sources in water resources of Kansas by minor alkali metal and halide chemistry. Kansas Water Resources Research Institute, Consultant's Report to Office of Water Research and Technology, U.S. Department of the Interior, Washington, D.C.

Winslow, J. D., H. G. Stewart, R. H. Johnston, and L. J. Crain. 1965. Groundwater resources of eastern Schenectudy County, New York, with emphasis on infiltration from the Mohawk River. State of New York Conservation Department Water Resources Commission Bulletin 57. 
Appendix A

INFORMATIOON ABOUT THE PACKED BOREHOLES"

\begin{tabular}{|c|c|c|c|c|}
\hline \multirow[t]{2}{*}{ Well } & \multicolumn{4}{|c|}{ Packed interval } \\
\hline & Depth (m) & Lithology & Formation & Group \\
\hline HHMS6a & 116 & Shale & Nolichucky & Conasauga \\
\hline WOL-2 & 268 & Snale & Rogersville & Conasauga \\
\hline WCR-2 & 155 & Dolomite & Copper Ridge & Knox \\
\hline $\mathrm{CH}-9$ & 116 & Shaly limestone & & Chickamauga \\
\hline $\mathrm{CH}-6$ & 116 & Shaly limestone & & Chickamauga \\
\hline
\end{tabular}


Appendix B

ION RATIOS IN BRINES, THE APPALACHIAN REGION

\begin{tabular}{|c|c|c|c|c|c|c|}
\hline Location & Source & Formation & $\begin{array}{l}\text { lo. of } \\
\text { amples }\end{array}$ & $\begin{array}{l}\mathrm{Na}: \mathrm{Cl} \\
(\mathrm{meq} / \mathrm{L})\end{array}$ & $\begin{array}{l}\mathrm{Ca}: \mathrm{Na} \\
(\mathrm{meq} / \mathrm{L})\end{array}$ & $\begin{array}{l}\text { Br:Cl } \\
\text { (weight) }\end{array}$ \\
\hline w. Virginia & $\begin{array}{l}\text { Price et al. } \\
1937\end{array}$ & $\begin{array}{l}\text { Salt sand } \\
\text { Maxton Sand } \\
\text { Big Injun } \\
\text { Oriskany Sand }\end{array}$ & $\begin{array}{r}106 \\
19 \\
33 \\
6\end{array}$ & $\begin{array}{l}0.71 \\
0.70 \\
0.69 \\
0.73\end{array}$ & $\begin{array}{l}0.30 \\
0.30 \\
0.32 \\
0.28\end{array}$ & $\begin{array}{l}0.002 \\
0.0026 \\
0.0033 \\
0.0032\end{array}$ \\
\hline Ohio & $\begin{array}{l}\text { Stout et al } \\
1932\end{array}$ & $\begin{array}{l}\text { Big Lime } \\
\text { Maxville Sand } \\
\text { Big Lime } \\
\text { Maxville Sand } \\
\text { Keener Sand }\end{array}$ & $\begin{array}{l}1 \\
1 \\
1\end{array}$ & $\begin{array}{l}0.73 \\
0.69 \\
0.68\end{array}$ & $\begin{array}{l}0.3 \\
0.33 \\
0.34\end{array}$ & 0.001 \\
\hline Pennsylvania & $\begin{array}{l}\text { Rose \& Dresel } \\
1990\end{array}$ & Unknown & 7 & $0.58-0.75$ & $0.29-0.54$ & $0.002-0.005$ \\
\hline Kentucky & $\begin{array}{l}\text { Kreiger } \\
\text { et al. } 1957\end{array}$ & $\begin{array}{l}\text { Coniferous limestone } \\
\text { Berea }\end{array}$ & $\begin{array}{l}1 \\
1\end{array}$ & $\begin{array}{l}0.85 \\
0.98\end{array}$ & & \\
\hline Tennessee & $\begin{array}{l}\text { E. Holliday } \\
\text { pers. comm. }\end{array}$ & Cambrian-Ordovician & 6 & $0.47-0.87$ & $0.12-1.05$ & \\
\hline Tennessee & $\begin{array}{l}\text { ORR } \\
\text { Haase \& Stow } \\
\text { 1987; Switek } \\
\text { et al. } 1987\end{array}$ & Cambrian-Ordoviciam & $35^{a}$ & $0.36-1.8$ & $0.02-0.6$ & $0.014-0.0055$ \\
\hline
\end{tabular}

\footnotetext{
${ }^{a}$ Ion ratios were calculated only for analyses that had reaction error $<10 \%$
} 
Appendix C

\section{INFORMATION ABOUT THE OLL AND GAS WELLS SAMPLED FOR THIS STUDY}

\begin{tabular}{lccc}
\hline Well name & $\begin{array}{c}\text { Carter } \\
\text { coordinates }\end{array}$ & $\begin{array}{c}\text { Total } \\
\text { depth (ft) }\end{array}$ & $\begin{array}{l}\text { Producing } \\
\text { interval }\end{array}$ \\
\hline American Resources Management No. 4 & $5-6 S-63 E$ & 3045 & Monteagle \\
B\&W Oil Comp. No. 1 BW & $13-5 S-57 E$ & 3975 & Knox \\
B\&W Oil Corp. Plateau Properties & $20-5 S-56 E$ & 1672 & Monteagle \\
Bobby Morgan No. 1 & $12-7$ S-55E & 1730 & Monteagle \\
\hline
\end{tabular}


ORNL/GWPO-003

\section{INTERNAL DISTRIBUTION}

1. L. D. Bates

2. F. P. Baxter

3. H. L. Boston

4. J. B. Cannon

5. R. B. Clapp

6. J. H. Cushman

7. R. B, Dreier

8. T. O. Early

9. N. D. Farrow

10. J. M. Forstrom

11. D. E. Fowler

12. C. W. Gehrs

13. S. M. Gregory

14. C. S. Haase

15. S. G. Hildebrand

166. D. D. Huff

17. A. E. Hunley

18. S. B. Jones

19. P. Kanciruk

20. R. O. Kennard

21. P. J. Lamiszki
22. W. McMahon

23. B. W. McMaster

24. G. K. Moore

25-29. R. Nativ

30. D. E. Reichle

31. C. T. Rightmire

32. F. E. Sharples

33. L. A. Shevenell

35. L. G. Shipe

36. D. S. Shriner

37. D. K. Solomon

38. S. H. Stow

39. L. E. Toran

40. R. I. Van Hook

41. T. F. Zondlo

42. Central Research Library

43. ER Document Management Center

44-58. ESD Library

59-60. Laboratory Records Dept.

61. ORNL Patent Section

62. ORNL Y-12 Technical Library

\section{EXTERNAL DISTRIBUTION}

63. Office of Assistant Manager for Energy Research and Development, DOE Oak Ridge Operations Office, P.O. Box 2001, Oak Ridge, TN 37831-8600

64. G. W. Bodenstein, DOE Oak Ridge Field Office, P.O. Box 2001, Oak Ridge, Tennessee 37831-8541

65. R. M. Farvolden, Professor, Department of Earlth Sciences, University of Waterloo, Waterloo, Ontario N2L 3G1 Canada

66. J. F. Franklin, Bloedel Professor of Ecosystem Analysis, College of Forest Resources, University of Washington, Anderson Hall AR-10, Seattle, WA 98195

67. R. C. Harriss, Institute for the Study of Earth , Oceans, and Space, Science and Engineering Research Building, University of New Hampshire, Durham, NH 03824

68. G. Y. Jordy, Director, Office of Program Analysis, Office of Energy Research, ER-30, G226, U.S. Department of Energy, Washington, DC 20545

69. R. H. Olsen, Professor, Microbiology and Immunology Department, University of Michigan, Medical Sciences II, \#5605, 1301 East Catherine Street, Ann Arbor, MI 481090620

70. A. Patrinos, Director, Environmental Sciences Division, Office of Health and Environmental Research, ER-74, U.S. Department of Energy, Washington, DC 20585

71. F. J. Wobber, Environmental Sciences Division, Office of Health and Environmental Research, ER-74, U.S. Department of Energy, Washington, DC 20585

72-73. Office of Scientific and Technical Information, P.O. Box 62, Oak Ridge, TN 37831 

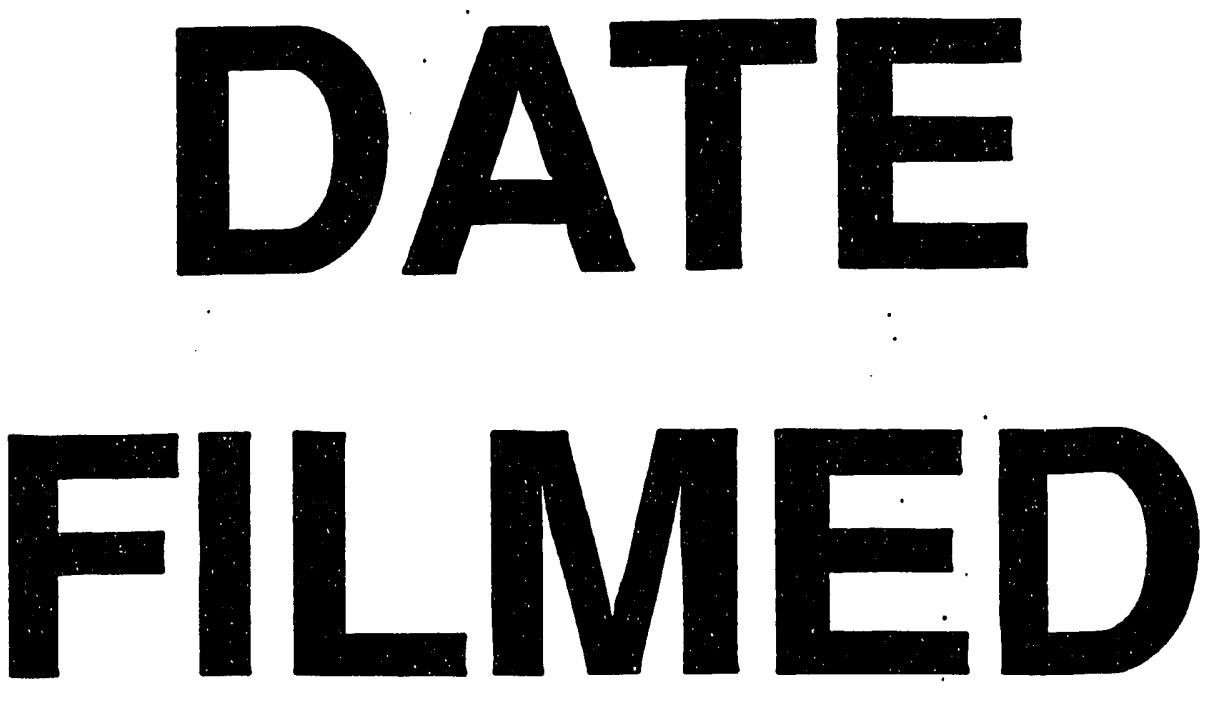

$10 / 12 / 93$
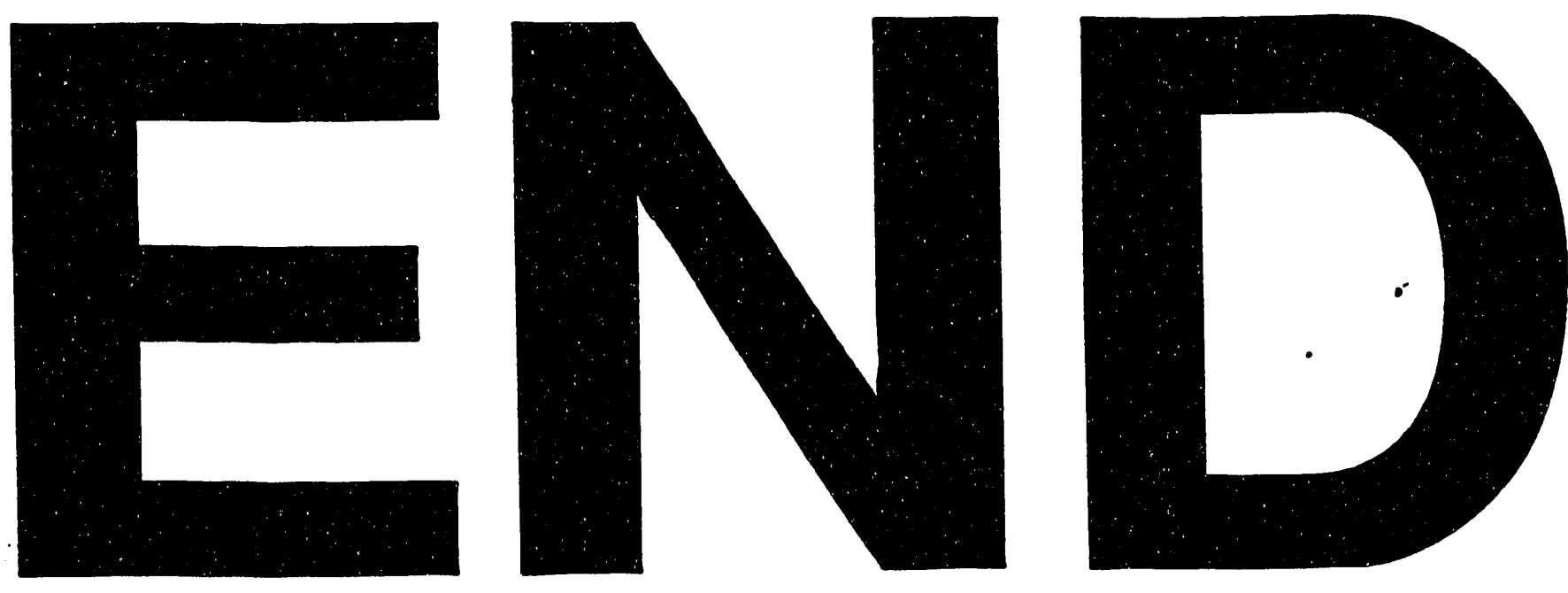
